\title{
Toxicity, Bioaccumulation and Depuration of Bromoform in Five Marine Species
}

Protothaca stamineae, Littleneck Clam

Mercenaria mercenaria, Eastern Hard Clam, Quahog

Crassostrea virginica, Eastern Oyster

Penaeus aztecus, Brown Shrimp

Brevoortia tyrannus, Atlantic Menhaden

Prepared by C. I. Gibson, F. C. Tone, P. Wilkinson, J. W. Blaylock, R. E. Schirmer

Pacific Northwest Laboratory

Operated by

Battelle Memorial Institute

Prepared for

U.S. Nuclear Regulatory

Commission 


\section{NOTICE}

This report was prepared as an account of work sponsored by an agency of the United States Governmert. Neither the United States Government nor any agency thereof, or any of their employees, makes any warranty, excressed or implied, or assumes any legal liability or responsibility for any third party's use, or the results of such use. of any information. apparatus product or process disciosed in this report, or represents that its use by such third party would not infringe privately owned rights.

\section{Available from}

\section{GPO Sales Program}

Division of Technical Information and Document Control

U. S. Nuclear Regulatory Commission Washington, D. C. 20555

Printed copy price: $\$ 3.50$.

and 


\section{Toxicity, Bioaccumulation and Depuration of Bromoform in Five Marine Species}

Protothaca stamineae, Littleneck Clam

Mercenaria mercenaria, Eastern Hard Clam, Quahog

Crassostrea virginica, Eastern Oyster

Penaeus aztecus, Brown Shrimp

Brevonttia tyrannus, Atlantic Menhaden

Manuscript Completed: August 1980

Date Published: January 1981

Prepared by

C. I. Gibson, F. C. Tone, P. Wilkinson, J. W. Blaylock, R. E. Schirmer

Pacific Northwest Laboratory

Richland, WA 99352

Prepared for

Division of Safeguards, Fuel Cycle and Environmental Research

Office of Nuclear Regulatory Research

U.S. Nuclear Regulatory Commission

Washington, D.C. 20555

NRC FIN No. B2098 



\section{ABSTRACT}

Bromoform has been identified as the single most abundant halogenated organic compound produced by the chlorination of marine waters. To determine the potential biological effects of its release into marine waters, short-term toxicity bioassays and 28-day uptake/28-day depuration studies were conducted with five marine species: Protothaca staminea, Mercenaria mercenaria, Crassostrea virginica, Penaeus aztecus, and Brevoortia tyrannus. The bioassay studies indicate that 96-hr LC50s ranged from approximately $7 \mathrm{ppm}$ for B. tyrannus to greater than $40 \mathrm{ppm}$ for $P$. staminea. Behavioral changes were noted in $P$. aztecus and $B$. tyrannus exposed to subiethal concentrations of bromoform.

In all species tested, the uptake and depuration of bromoform was rapid. Bromoform was present in a 17 exposed animal tissues within 24 hours and was depurated within 48 hours. In the mollusk species, there was bioaccumulation above water concentrations in the first week of exposure, and then the tissue concentrations fell to levels approximately equal to the water concentrations. The shrimp and menhaden also bioaccumulated bromoform above water concentrations in the first week of exposure, but then the tissue concentrations fell to approximately $0.4 \mathrm{\mu g} / \mathrm{g}$ and remained at this level independent of water concentrations. 



\section{SUMAMARY}

The investigation of the by-products created by the chlorination of sea water showed that bromoform was the major halogenated organic formed. To determine the potential for environmental effects of bromoform and its possible return to man, a study was undertaken to test its toxicity and uptake with five commercial and recreationally important species. The species to be tested, Protothaca staminea (Pacific littleneck clam), Mercenaria mercenaria (Eastern hard clam or quahog), Penaeus aztecus (brown shrimp) and Brevoortia tyrannus (Atlantic menhaden) were selected by NRC. These species have commercial and economic importance and are often found in the vicinity of discharge streams from nuclear fueled steam electric stations.

The research approach was to run a series of 96-hr LC50 screening bioassays to determine the relative toxicity of bromoform and to run a standard 28-day uptake/28-day depuration test. These studies would provide the information needed to determine the necessity of further testing.

The initial problem of the study was the development of a method to introduce bromoform into sea water in a manner that would result in a bromoform/seawater solution. This was to be done in a flow-through system to provide test conditions that were as similar as possible to the conditions an animal may experience in the environment.

The introduction of bromoform into sea water in a soluble form turned out to be very difficult. When liquid-to-liquid mixing was attempted, bromoform tended to pool together in the bottom of the mixing vessel and was slow to go into solution. In addition, a large excess of bromoform was required to bring a given volume of sea water to the saturation level. These features made it impractical to use liquid-toliquid mixing to provide the needed quantities of seawater/bromoform solutions for the desired toxicity and uptake testing. The sparging of air saturated with bromoform into sea water was found to be the most satisfactory method of producing the desired concentrations of bromoform in sea water under the conditions needed to perform the tests.

Testing of the eastern species was conducted at the Battelle Marine Research facility located in Daytona Beach, Florida, and testing of the west coast species was conducted at the Sequim, Washington, Marine Research laboratory. Analysis of the sea water for bromoform was conducted at the Sequim laboratory. To insure that the transport of the samples to Sequim would not affect the concentration, both storage and shipping tests were conducted with known samples. Under all situations there were no significant changes caused by either storage or shipping. 
Preliminary testing of the littleneck clam indicated that a standard 96-hr LC50 would be impractical. At concentrations of bromoform that caused death, Tjttleneck clams would close up and die in the shut position, making it difficult to determine if the clam was dead or when it died. At lower concentrations, pumping by the clams appeared to be sporadic, making the actual exposure time variable depending on the individual clam's activity. Therefore, it was decided to conduct the 28-day uptake/28-day depuration test at $1,5,10$, and $20 \mathrm{mg}$ bromoform/ $\ell$ concentrations and to record the mortalities. It was felt that this would provide an estimate of the toxicity of bromoform in addition to the desired uptake data.

It was very difficult to maintain the target bromoform concentrations over the 28-day study period. The actual average concentrations were $2,7,19$, and $27 \mathrm{mg}$ bromoform $/ \ell$. Mortality occurred only in the 27 $\mathrm{mg} / \ell$ and $19 \mathrm{mg} / \ell$ test conditions. At $27 \mathrm{mg} / \ell$ average bromoform concentration, there was mortality on day 7 and day 25 ; at $19 \mathrm{mg} / \ell$ average bromoform concentration, mortality occurred only on day 25 .

At Daytona, all species were subjected to standard 96-hr tests using paired tanks. As at Sequim, there was difficulty producing mortalities in the mollusks because of their apparent tolerance to bromoform and their ability to close up and reduce their exposure time. Because of this, a standard LC50 value could not be calculated. However, based on latent mortality it was estimated that for these species the $96-\mathrm{hr}$ LC50 would be in the range of 40 to $140 \mathrm{mg} / \mathrm{l}$.

Testing of the menhaden and brown shrimp was successful. They had calculated $96-\mathrm{hr} L C 50$ values of $12 \mathrm{mg} / \ell$ and $26 \mathrm{mg} / \ell$, respectively. Both of these species exhibited behavioral changes at sublethal concentrations.

The 28-day uptake/28-day depuration tests were conducted at concentrations below those found to be lethal in the toxicity tests. However, even at these low concentrations some mortalities occurred in the menhaden and shrimp tests. These mortalities were probably due to the fact that it is difficult to hold these organisms for long periods of time in the laboratory without experiencing some mortality, even in the controls.

A1l the mollusk species (littleneck clams, quahogs, and oysters) had tissue concentrations that were reflective of the ambient water concentrations. There was some indication of increased concentrations (that is, tissue concentrations above water concentrations) during the first week of exposure, but the general tendency was for these to decrease with time and be equal to water concentrations. The bromoform was depurated from the mollusks within 24 to 48 hours after exposure stopped. 
The menhaden and shrimp had a different pattern of uptake. In menhaden, at an average water concentration of $0.21 \mathrm{mg} / \ell$, the tissue concentrations were high during the first week (up to $7.61 \mu \mathrm{g} / \mathrm{g}$ ) but then fell to near the water concentrations. At the lower test concentration $(0.04$ $\mathrm{mg} / \mathrm{\ell}$ ), the tissue concentrations remained around . $40 \mu \mathrm{g} / \mathrm{g}$, a factor of about 10 above water concentrations. The same phenomenon was roted in the shrimp. 


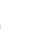




\section{TABLE OF CONTENTS}

$\begin{array}{lc}\text { Abstract } & i i j \\ \text { Summary } & v \\ \text { List of Figures } & x i \\ \text { List of Tables } & x i i j \\ \text { Preface } & x v \\ \text { Acknowledgments } & x v i i \\ \text { Introduction } & 1 \\ \text { Discussion } & 6 \\ \text { Conclusions and Recommendations } & 9 \\ \text { References } & 11\end{array}$ 



\section{LIST OF FIGURES}

1. Toxicant dei ivery system for seawater/bromoform

bioassays conducted at Sequim . . . . . . . . . . . . . . 19

2. A section of the bromoform exposure system used at the Daytona Beach Laboratory . . . . . . . . . . . . . . . . 19

3. Measured concentrations in Protothaca staminea exposure with target bromoform concentration of $20 \mathrm{mg} / \mathrm{h}$. . . . . . . . 20

4. Measured concentrations in Protothaca staminea exposure tank with target bromoform concentration of $10 \mathrm{mg} / \ell$. . . . . 20

5. Measured concentrations in Protothaca staminea exposure tank with target bromoform concentration of $5 \mathrm{mg} / \mathrm{l} . . . .21$

6. Measured concentrations in Protothaca staminea exposure tank with target bromoform concentration of $1 \mathrm{mg} / \ell . . .2 . .21$

7. Penaeus aztecus mortality bromoform concentration plot for calculation of 96-hr LC50 by the method of Litchfield and Wilcoxon (1949). . . . . . . . . . . . . . . . . . 22

8. Brevoortia tyrannus mortality bromoform concentration plot for $96-\mathrm{hr}$ LC50 calculation by the method of Litchfield and Wilcoxon (1949).................. . . 22

9. Crassostrea virginica latent mortality bromoform concentration plot used to determine concentration above which the 96-hr LC50 should fall . . . . . . . . . . . 23

1D. Mercenaria mercenaria latent mortality bromoform concentration plot used to determine concentration above which the 96-hr LC5D should fall . . . . . . . . . 23

11. Water and tissue concentrations of bromoform (Eastern oyster, Crassostrea virginica) 28-day uptake/28-day depuration studies. Target water bromoform was $1.0 \mathrm{mg} / \ell . . .24$

12. Water and tissue concentrations of bromoform (Eastern oyster, Crassostrea virginica) 28-day uptake/28-day depuration studies. $\frac{\text { target water bromoform was } 0.1 \mathrm{mg} / \ell . . .25}{2 .}$

13. Water and tissue concentrations of bromoform (Eastern oyster, Crassostrea virginica) 28-day uptake/28-day depuration studies. Control . . . . . . . . . . . . .26 
14. Water and tissue concentrations of bromoform (Quahaug, Mercenaria mercenaria) 28-day uptake/28-day depuration studies. Target water bromoform concentration was $1.0 \mathrm{mg} / \ell$. 27

15. Water and tissue concentrations of bromoform (Quahaug, Mercenaria mercenaria) 28-day uptake/28-day depuration studies. Target water bromoform concentration was $0.1 \mathrm{mg} / \ell . .28$

16. Water and tissue concentrations of bromoform (Quahaug, Mercenaria mercenaria) 28-day uptake/28-day depuration studies. Control................ . . . 29

17. Water and tissue concentrations of bromoform (Litt leneck clam, Protothaca staminea) 28-day uptake/28-day depuration studies. Target water bromoform concentration was $10 \mathrm{mg} / \ell, .30$

18. Water and tissue concentrations of bromoform (Littleneck clam, Protothaca staminea) 28-day uptake/28-day depuration studies. Target water bromoform concentartion was $1.0 \mathrm{mg} / \ell$. . 31

19. Water and tissue concentrations of bromoform (Littleneck clam, Protothaca staminea) 28-day uptake/28-day depuration studies. Control . . . . . . . . . . . . . . . . . 32

20. Water and tissue concentrations of bromoform (Menhaden, Brevoortia tyranus) 28-day uptake/28-day depuration studjes. Target water bromoform concentrations was $1.0 \mathrm{mg} / \ell$. . . . . . . . . . . . . . . . . 33

21. Water and tissue concentrations of bromoform (Menhaden, Brevoortia tyrannus) 28-day uptake/28-day depuration studies. Target water bromoform concentration was $0.1 \mathrm{mg} / \mathrm{\ell}$

22. Water and tissue concentrations of bromoform (Menhaden, Brevoortia tyrannus) 28-day uptake/28-day depuration studies. Control

23. Water and tissue concentrations of bromoform (Shrimp, Penaeus azectus) 28-day uptake/28-day depuration studies. Target water bromoform concentration was $1.0 \mathrm{mg} / \ell . .$. . . . 36

24. Water and tissue concentration of bromoform (Shrimp, Penaeus azectus) 28-day uptake/28-day depuration studies. Target water bromoform concentration was $0.1 \mathrm{mg} / \mathrm{l}$

25. Water and tissue concentrations of bromoform (Shrimp, Penaeus aztecus) 28-day uptake/28-day depuration studies. Control 


\section{LIST OF TABLES}

1. Concentration of bromoform $(\mathrm{mg} / \mathrm{l})$ in tank at time of noted clam responses. . . . . . . . . . . . . . . . . 12

2. Measured bromoform concentrations $(\mathrm{mg} / \mathrm{l})$ in Protothaca staminea in exposure tanks . . . . . . . . . . . . . 13

3. Bromoform concentration in each test organism for Eastern oyster (Crassostrea virginica) $(\mu \mathrm{g} / \mathrm{g}$ tîssuewet weight ). . . . . . . . . . . . . 14

4. Bromoform concentration in each test organisms for Quahaug (Mercenaria mercenaria) $(\mu \mathrm{g} / \mathrm{g}$ tissuewet weight)................... . . 15

5. Average ( $\bar{x}$ ) Body Burden and Standard Deviation (S.D.) for littleneck clam (Protothaca staminea ( $\mu \mathrm{g} / \mathrm{g}$ tissuewet weight).................... 16

6. Bromoform concentration in each test organism for menhaden (Brevoortia tyrannus) $(\mu \mathrm{g} / \mathrm{g}$ tissuewet weight).................. . . 17

7. Bromoform concentration in each test organism for shrimp (Penaeus aztecus) $(\mu \mathrm{g} / \mathrm{g}$ tissuewet weight) ................. 18 



\section{PREFACE}

This report includes data and analysis for the Marine Biology Task of the program on Biocide By-Products in Aquatic Environments.

Reports prepared for the entire program are:

Title

- Investigation of Halogenated Components Formed from Chiorination of Natural Waters: Preliminary Studies, NUREG/CR- 1299

- Acute Toxicity and Bioaccumulation of Chioroform to Four Species of Fresh Water Fish Salmo gairdneri, Rainbow Trout [epomis macrochirus, Bluegill Micropterus salmoides, Largemouth Bass Ictalurus punctatus, Channe] Catfish, NUREG/CR-0893

- Chronic Effects of Chlorination By-Froducts on Rainbow Trout, Salmo gairdneri, MUREG/CR-0892

- Toxicity, Bioaccumulation and Depuration of Bromoform in Five Marine Species Protothaca staminea, Littleneck Clam Mercenaria mercenaria, Eastern Hard Clam, Quahog Crassostrea virginica, Eastern oyster Penaeus aztecus, Brown Shrimp Brevoortia tyrannus, Atlantic Menhaden, NUREG/CR-1297

- Growth and Histological Effects to Protothaca staminea, (Littieneck Clam) of Long-Term Exposure to Chlorinated Sea Water, NUREG/CR-1298

- Analysis of Organohaiogen Products from Chlorination of Natural Waters Under Simulated Biofouling Control Conditions, NUREG/CR-1301

- Biocide By-Products in Aquatic Environments, Final Report Covering Period September 10, 1976 through September 30, 1979, NUREG/CR-1300
Author

Roger M. Bean Robert G. Riley

David R. Anderson E. William Lusty

David R. Anderson Roger M. Bean Roger E. Schirmer

Charles I. Gibson Fredrick C. Tone Peter tilkinson J. W. Blaylock Roger E. Schirmer

Charles I. Gibson Robert E. Hillman Peter Wilkinson Dana L. Woodruff

Roger M. Bean Dale C. Mann Robert G. Riley

Roger M. Sean Charles I. Gibson David R. Anderson 



\section{ACKNOWLEDGMENTS}

This work was performed for the U.S. Nuclear Regulatory Commission (NRC) under a Related Services Agreement with the U.S. Department of Energy Contract DE-AC06-76RL0-1830. The author wishes to acknowledge the guidance and assistance provided by Dr. Phillip R. Reed of NRC.

Contributors to this report are:
C. I, Gibson
F. C. Tone
P. Wilkinson
J. W. Blaylock
R. E. Schirmer

Principal Investigator, Manager, Marine Sciences Section Scientist

Technical Support Specialist Technical Support Specialist Scientist

Trade names and registered trademarks are used to assist the reader in replicating the experiments. Their use does not constitute endorsement by Battel le Memorial Institute or the U.S. NRC. 



\section{INTRODUCTION}

Bromoform was identified by Bean et al., (1980) as the major halogenated organic produced by the chlorination of Sequim Bay, Washington sea water. As part of the NRC program to determine the toxic and bioaccumulation potential for chlorination by-products, a series of tests were undertaken to determine the acute toxicity and bioconcentration potential for bromoform. The test organisms were selected, in conjunction with NRC, as species that would have a high potential for exposure to the cooling water discharge streams of nuclear-fueled steam electric stations and were of commercial and/or recreational importance. These species, Protothaca staminea (the Pacific littleneck clam), Crassostrea virginica (the Eastern oyster), Mercenaria mercenaria (the Eastern hard clam, or quahaug), Penaeus aztecus (the brown shrimp), and Brevoortia tyrannus (the Atlantic menhaden) were to be used in 96-hour LC50 tests and 28-day uptake/28-day depuration tests. To avoid animal transportation problems, the studies with the Pacific littleneck clam were conducted at the Battelle Marine Research Laboratory, Sequim Bay, Washington, and the studies with the other four species were conducted at the Daytona Beach Marine Laboratory, Daytona Beach, Florida.

Toxicity

Methods and Materials (Sequim):

The first problem that needed to be solved before the toxicity and bioaccumulation testing could be conducted was the delivery of bromoform in solution to the test organisms. Initial tests to produce bromoform/ seawater solutions at concentrations desired for the toxicity testing by liquid-to-liquid contact failed. When bromoform was mixed directly with sea water, a large portion would remain in droplet form and eventually settle to the bottom of the tank. The mixing of bromoform and sea water for long periods (24 to 48 hours) did produce bromoform/ seawater solutions with desired bromoform concentrations, but the procedure was too inefficient and time consuming to be useful in providing sufficient toxicant stock solutions for flow-through systems. As a confounding factor, the availability of bromoform from United States suppliers dried up, creating a situation where the quantity of bromoform available for use in the tests was limited.

The system that was finally developed and selected for use in the toxicity and bioaccumulation tests was the air sparge method diagrammed in Figures 1 and 2. Figure 1 is the system used at Sequim, and Figure 2 is the system used at Daytona. The basic concept is to flow compressed air into a flask containing bromoform. The exhaust from this flask is carried by silicone tubing to either the test tank as in the case in Figure 1 , or a mixing/splitter tank as is the case in Figure 2 . The concentration of bromoform in the sea water is regulated by the airflow rate and seawater flow rate. 
In preparing to conduct the toxicity test with Protothaca staminea, it was found that at high concentrations (greater than $600 \mathrm{mg}$ bromoform $/ \ell$ ) the clams would close up and die in the closed position. Clams were then tested for their sensitivity to bromoform. In this test, we observed five littleneck clams which were placed in a tank receiving clean, running, filtered Sequim Bay sea water. When all five clams had extended their siphons, a bromoform/seawater solution was introduced into the flowing sea water entering the tank. A water sample was callected for bromoform analysis when the first response was noted (siphons slightly retracted), again when all siphons were retracted except one which was again extended, and when all siphons were retracted (Table 1). The flow of bromoform/seawater was continued for 4 hours and then stopped. After one hour, the siphons again extended. The clams were held for 96 hours in clean, running sea water with no mortality.

These preliminary tests, the short supply of bromoform, and the data which indicated that in the real-world situation bromoform would be present at 30 to $80 \mu \mathrm{g} / 2$ concentrations, resulted in the decision to conduct the 28-day exposure studies at bromoform concentrations of 1 , 5,10 , and $20 \mathrm{mg} / \ell$ and observe mortality. The mortality data could then be used to estimate the concentration range of the LC50 and, if warranted, toxicity testing to further refine the LC50 point could be undertaken. Organisms from the lower concentrations ( 1 and $10 \mathrm{mg} / \mathrm{l}$ ), would be used for the bioaccumulation studies.

\section{Collection and Exposure (Sequim)}

Specimens of $P$. staminea were collected from Sequim Bay, Washington, and held in unfiltered, ambient running sea water for four days prior to testing. There was less than $1 \%$ mortality during the holding period. The exposure of $P$. staminea was conducted by bubbling air saturated with bromoform (Eastman Spectrograde ${ }^{\text {(S) }}$ ) directly into the exposure tanks (Figure 1). The tanks were 30-1iter glass aquaria layered with approximately $5 \mathrm{~cm}$ of coarse sand. Seventy-five clams were randomly selected and placed in each tank. Concentration of bromoform and mortality was monitored five days a week (Monday through Friday). Bromoform/air flows were adjusted to maintain nominal concentrations of $0,1,5,10$, and $20 \mathrm{mg} / \ell$.

Water quality was not monitored. Previous studies have shown the water qua? ity to be stable with only slight seasonal variation.

Salinity ranges seasonally from 29 to $31 \mathrm{ppt}$, and temperature from $7^{\circ}$ to $13^{\circ} \mathrm{C}$. Oxygen is normally at $100 \%$ saturation $(9.4 \mathrm{mg} / \mathrm{l})$ except in late August and September when concentrations down to $80 \%$ saturation have been observed. Water samples for bromoform analysis were collected and stored under refrigeration. 
Collection and Exposure (Daytona)

Bromoform exposures with four marine species (Crassostrea virginica, Mercenaria mercenaria, Brevoortia tyrannus, and Penaeus aztecus were conducted at Battelle's Florida Marine Research Facility in Daytona Beach, Florida. With the exception of shrimp which were purchased from a local bait dealer, clams, oysters, and juvenile menhaden were collected by Battelle staff members in the Halifax River within one mile of the Florida Marine Research Facility. Shrimp and menhaden were held in 11,350- 2 outdoor circular holding tanks with a continuously flowing supply of halifax River sea water, filtered through sand and activated carbon. Purina Trout Chow was fed at a daily rate of $5 \%$ body wt. Clams and oysters, held in 265- 2 fiberglass water tables, were supplied with unfiltered water as a food source. Clams were placed in $5 \mathrm{~cm}$ of fine beach sand. All organisms were held for at least one week prior to exposure with less than $1 \%$ mortality. Average organism individual wet weights were as follows: shrimp - $3.3 \mathrm{~g}$, oysters - $75 \mathrm{~g}$, clams - $141 \mathrm{~g}$, and menhaden - $3.5 \mathrm{~g}$.

During all exposures, salinity, temperature, dissolved oxygen, $\mathrm{pH}$, behavior, mortality and bromoform water concentrations were monitored daily.

In June, 1978 two 96-hr exposures with 5 concentrations plus a control for each were made with shrimp. Each exposure consisted of 12 paired tanks with two tanks for each concentration plus two controls. Ten shrimp were placed in each tank. The first exposure was initiated on June 20 , and the second on June 29.

A series of 12 paired tanks were used for simultaneous exposures of menhaden and oysters. This consisted of two controls and two tanks for each of 5 exposure concentrations; one containing 10 juvenile menhaden and the other containing 10 oysters. T! $\quad$, :...ient was initiated on July 24, 1978. Due to the rapid onsei ur mortalities of menhaden at the three highest concentrations, mortality data was taken after 2 and 5 hours of exposure and daily thereafter. Daily observations of oysters included noting filtering activity in each tank. Oysters were observed for four days after exposure for latent mortality.

Six tanks were used for clam exposures; 5 bromoform concentrations plus one control. The experiment was initiated on 0ctober 2, 1978. Filtering activity was noted daily, and clams were also monitored for four days following exposure for latent mortality.

Uptake and Depuration

For the $P$. staminea tests, the target bromoform concentrations were 0 (contro 1 ), 1 and $10 \mathrm{mg} / 2$. However, because these concentrations were 
impossible to maintain, the average measured concentrations are given in the tables 1 isting the results. Target concentrations of 0 (control), $0.1 \mathrm{mg} / \ell$ and $1.0 \mathrm{mg} / \ell$ were used in the tests with $C$. virginica, $M$. mercenaria, $B$. tyrannus and $P$. aztecus. All four species were exposed simultaneousTy for this 28-day uptake/28-day depuration experiment. Sixty organisms ( 30 placed in each of a tank pair) of each species were exposed to each target concentration, thereby requiring 12 pairs of 24 exposure tanks. Subsamples of five P. staminea and three each of the other four species were harvested on days $0,1,2,4,7,14$, 21,28 of the uptake phase and day $1,2,4,7,21$ and 28 of the depuration phase. P. staminea specimens were frozen in glass jars for later analysis. Specimens of the other species were frozen in collapsed plastic zip-lock bags which were then sealed in $1 \ell$ plastic wide mouth jars. In some cases, mortality reduced the number available so the smaller sample groups were collected during the latter phase of the test.

\section{Bromoform Analysis (Water)}

Water samples collected from the bioassay tanks were stored in tightly capped and completely filled $60-\mathrm{m} \ell$ bottles at $4^{\circ} \mathrm{C}$ prior to analys is. Subsampies ( 5 to $10 \mathrm{ml}$ ) were removed from the bottles and transferred to 25 me screw-cap vials containing 10 me hexane. The vials were hand-shaken for 90 seconds and allowed to stand until phase separation occurred. One me of the hexane phase was transferred to a 1 me Hewlett Packard autosampler vial with septum cap. An internal standard was then added to the vial by syringe ( $3 \mu \mathrm{l}$ of $152 \mu \mathrm{g} / \mathrm{ml}, 1,3$-dibromopropane). The samples were then analyzed by electron capture gas chromatography, utilizing a Hewlett Packard model $5840^{\circ}$ with autosampler.

The analysis conditions were as follows: Column - 30 meter SP2100 glass capillary with 15 to 1 split ratio; carrier gas - helium; oven temperature $-85^{\circ} \mathrm{C}$, detector $-6{ }^{6} \mathrm{Ni}$ electron capture. Calculation of sample concentration was conducted by the internal standard calibration method.

\section{Bromoform Analysis (Tissue)}

Tissues were analyzed for bromoform by homogenizing the tissue in water at $0^{\circ} \mathrm{C}$ and diluting with enough water to obtain a concentration of approximately $I \mathrm{~g}$ tissue/10 me tissue suspension. Aliquots (10-20 $m \ell)$ of the aqueous tissue suspension were extracted with two 5-me portions of hexane containing 1,3-dibromopropane as an internal standard. The microliter samples of the hexane solution were injected into a gas chromatograph fitted with an $18-i n$. Porapak $Q^{B}$ column and a ${ }^{63} \mathrm{Ni}$ electron-capture detector. The column was operated at $185^{\circ} \mathrm{C}$. The limit of detection of this procedure was $0.0005 \mu \mathrm{g} / \mathrm{g}$, and the coefficient of variation ranged from $1 \%$ at the $1^{-}$to $8-\mu \mathrm{g} / \mathrm{g}$ leve 1 to $3 \%$ at levels below $0.1 \mu \mathrm{g} / \mathrm{g}$. The coefficient of variation was calculated from 16 replicate analyses of each of 9 tissue samples. 


\section{LC50 Calculations}

For the menhaden and shrimp, 96-hr LC50 concentrations were calculated by the methods of Litchfield and Wilcoxon (1949). The LC50 concentrations were estimated by the same method from the latent mortality in the case of the quahog and Eastern oyster. No LC50 concentration value was calculated for the Pacific littleneck clam.

\section{TOXICITY RESULTS AND DISCUSSION}

\section{Protothaca staminea}

Considerable difficulty was experienced in maintaining the desired bromoform concentrations. At the highest level (nominal $20 \mathrm{mg} / \ell$ ), the average of 20 values for the 28-day exposure was $27 \mathrm{mg} / \ell$ with a range from $9 \mathrm{mg} / \ell$ to $76 \mathrm{mg} / \ell$ (Table 2). A plot of the concentrations measured are given in Figure 3 . The other exposure tanks had similar variation (Figures 4, 5, and 6) and averaged $2 \mathrm{mg} / \ell, 7 \mathrm{mg} / \ell$, and $19 / \ell$ for the target concentrations of 1,5 , and $10 \mathrm{mg} / \ell$, respective $1 \mathrm{y}$.

Mortality was observed only in the two higher concentrations. At the highest concentrations (average $27 \mathrm{mg} / \ell$ ), 21 of $60 \mathrm{clams}$ were found dead on day 7 of the exposure, and then 10 of 24 clams were found dead on day 25 . In the $10 \mathrm{mg} / \ell$ exposure (average concentration of 19 $\mathrm{mg} / \mathrm{l}$ ), 9 of $45 \mathrm{clams}$ were found dead on day 25 . During the depuration cycle of the test, two more mortalities occurred at the highest concentrations, one recorded on day 4, and one recorded on day 7 . The exact day of death for these individuals could not be determined. Df interest is the fact that no mortalities occurred at the lower two test levels through the 28-day uptake or 28-day depuration period.

\section{Penaeus aztecus}

The calculated $96-\mathrm{hr}$ LC50 for $P$. aztecus was $26 \mathrm{mg} / \ell$ with a $95 \%$ confidence interval between $33 \mathrm{mg} 7 \ell$ and $20 \mathrm{mg} / 2$ (Figure 7 ). Of interest was the behavior exhibited by the shrimp at two levels of concentration. At bromoform concentrations of $19 \mathrm{mg} / \ell$ and above, an avoidance response to the bromoform source occurred within 60 seconds of exposure. At concentrations of $31 \mathrm{mg} / \ell$ and above, a narcotic-like effect, where the shrimp were observed lying on their sides on the bottom of the tank with their abdominal appendages undulating, occurred within 120 minutes and continued throughout the experiment or until death.

Brevoortia tyrannus

The calculated $96-\mathrm{hr}$ LC50 for B. tyrannus was $12 \mathrm{mg} / \ell$ with a $95 \%$ confidence interval between $15^{-} \mathrm{mg} / \mathrm{l}$ and $\overline{9} \mathrm{mg} / \mathrm{l}$ (Figure 8 ). As the menhaden approached death they began to lose equilibrium and lay on their sides at the bottom of the tank. Opercular movement gradually decreased until all movement stopped. 
Crassostrea virginica and Mercenaria mercenaria

A 96-hr exposure period appears to be inadequate to generate meaningful 1 C50 data on clams and oysters. At concentrations above $10 \mathrm{mg} / \ell$, filtering ceases and the bivaives close and remain closed for much of the exposure period. At the end of 96 hours there were no mortalities with either $M$. mercenaria or $C$. virginica. However, mortalities occurred during the 3-day period immediately following the 96 hours of exposure to bromoform. Based on this latent mortality data, the $50 \%$ mortality concentration of $C$. virginica and $M$. mercenaria was estimated to be in the range of $40 \mathrm{mg} 7 \ell$ and $140 \mathrm{mg} / \ell$, respectively (Figures $9 \& 10$ ).

\section{DISCUSSION}

The results of the bioassays indicate that bromoform does not cause acute effects to the species tested at concentrations below $1 \mathrm{mg} / \ell$. Menhaden were the most sensitive, with a $96-\mathrm{hr}$ LC50 of $12 \mathrm{mg} / \mathrm{l}$. Shrimp were next in sensitivity with a $96-h r$ LC50 of $26 \mathrm{mg} / \ell$. The bivalves tested had $96-\mathrm{hr}$ LC50's that were apparently above $40 \mathrm{mg} / \mathrm{l}$. These bromoform concentrations are well above those one would expect in a power plant discharge, based on the findings of Carpenter and Smith (1978) and Bean et al. (1978). They reported bromoform concentrations of 30 to $350 \mathrm{ppb}$ in sea water that had been chlorinated at a rate of 1 to $4 \mathrm{ppm}$. This is a conversion rate of about 0.02 to 0.08 parts bromoform for each part chlorine added; for this conversion rate, chlorine would have to be added at a rate of $500 \mathrm{mg} / \ell$ to form sufficient bromoform to cause acute effects. At this rate of chlorination (unless there is an extremely heavy chlorine demand), the residual oxidant will have a much more pronounced effect than bromoform. The literature reports that total resudual oxidant causes acute effects to the tested species in the $1.5 \mathrm{mg} / \ell$ to $0.005 \mathrm{mg} / \ell$ range (Roberts et a1., 1975; Thatcher, 1978; Scott et al., 1978).

The mortalities noted in the $P$. staminea $27 \mathrm{mg} / \ell$ uptake/depuration exposure are curious in that they appear to have occurred at two single points in time. Both occurrences were four days after peak exposure concentrations were experienced (Figure 3 ). The first mortality occurred after a peak of $56 \mathrm{mg} / \ell$ bromoform, and the second occurred after a peak of $76 \mathrm{mg} / \ell$ bromoform. Thus, in this exposure tank it appears that there may be threshold concentration above which mortality begins.

The mortality that occurred in the $19 \mathrm{mg} / \ell$ exposure did not follow the pattern found at the higher level. The concentration in this system was not as variable as in the $27 \mathrm{mg} / \ell$ exposure, and the mortality did not occur until ten days after a peak concentration occurred. 
The delayed mortalities noted in the oyster tests, and the above clam mortalities indicate that the action of the bromoform at high concentrations can cause severe enough damage to prevent recovery. This action can result from short-term exposure to high concentrations (probably greater than $50 \mathrm{mg} / \ell$ ) or longer term exposure to lower concentrations in the 20 to $30 \mathrm{mg} / \ell$ range. In regard to concern about the release of bromoform from steam electric stations, the exact concentrations required for either short-term or long-term mortality is academic since these levels are approximately 1000 times those expected to be found.

At sublethal concentrations, the menhaden and shrimp exhibited some qualitative behavioral changes. After 48 hours, juvenile (under $7 \mathrm{~cm}$ T.L.) menhaden exposed to $6 \mathrm{mg} / \ell$ and $9 \mathrm{mg} / \ell$ bromoform exhibited extreme excitation to external stimuli such as loud noises, quick movements or sudden light changes. These stimuli would cause the fish to swim rapidly in random directions and frequently collide with the tank walls. In control tanks and at the higher concentrations, this response did not occur. This excitability continued for up to 20 days after the exposure to bromoform had been terminated.

The shrimp responded similarly at bromoform concentrations between 0.4 $\mathrm{mg} / \ell$ and $6 \mathrm{mg} / \mathrm{l}$. However, at concentrations below $3 \mathrm{mg} / \ell$ the response was no longer evident within one hour after bromoform addition was stopped. At concentrations between $3 \mathrm{mg} / \ell$ and $6 \mathrm{mg} / \ell$, the response continued for at least one day.

These observations are qualitative but in complete opposition to the response noted for those organisms that died. At the higher levels, the bromoform appeared to act as a narcotic. Both shrimp and menhaden gradually slowed down, lost orientation and eventually stopped pleopod or opercular movement. This condition was reversible for the shrimp, which recovered within a few hours if the bromoform input was stopped before pleopod motion ceased.

Based on the 96-hr LC50 studies and mortality data from the uptake and depuration studies, the potential for acute environmental effects (to the studied species) from bromoform created through chlorination of steam electric station cooling waters is minimal. The behavioral responses noted should be considered subjective observations that may or may not be related to bromoform exposures. To determine if the behavioral responses noted are, in fact, real changes and caused by bromoform, further research will be necessary.

\section{RESULTS AND DISCUSSION (Uptake and Depuration)}

The results of the tissue analyses are presented in Tables 3 through 7. The average body burdens of bromoform of each harvest date are plotted with the daily water bromoform concentrations in Figures 11 through 25. 
It was difficult to hold the water-bromoform concentrations within the desired target concentrations, so it is the average concentrations for the 28-day exposure period that are listed in the tables. However, in discussion about concentration factors, the body burdens are compared to the water concentration on the day of harvest.

In general, the three molluscan species $P$. staminea, $C$. virginica and $M$. mercenaria had tissue concentrations that were about equal to the water concentrations. There were several exceptions to this generalization, the most notable of which was the high body concentration (11.59 $\mathrm{mg}$ bromoform $/ \mathrm{g}$ tissue) found on day 14 in the $1 \mathrm{mg}$ bromoform $/ \ell$ c. virginica test. The $11.59 \mathrm{mg}$ bromoform/g tissue is a concentration factor of approximately 15, three times higher than any other concentration factor observed for the oysters. However, that particular oyster and three others appear to be exceptions to the general trend of body burdens, which are approximately the same as water concentrations (Figure 1). At $0.1 \mathrm{mg}$ bromoform $/ \ell$ the tissue concentrations were close to the water concentrations on the day of harvest.

M. mercenaria body burdens in the $1.0 \mathrm{mg}$ bromoform $/ \ell$ test followed the water concentrations during the first week but remained lower than the water for the rest of the exposure. At $0.1 \mathrm{mg}$ bromoform/ $\ell$ the body burdens were slightly above the water concentrations but, in general, followed the water levels closely except for a single incidence on day 28. P. staminea tissue concentrations were also similar to the water concentrations on day of harvest.

Menhaden and shrimp were different from the molluscs, showing body burdens higher than the water concentrations at the $0.1 \mathrm{mg}$ bromoform exposure condition; at $1.0 \mathrm{mg}$ bromoform/ $\ell$ they were higher than the water during the first week but then fell to approximately the water concentration level for the remaining three weeks. The control organisms also had significant levels of bromoform in their tissues during the period when bromoform was introduced into the other test systems. In fact, even though the exposure systems were completely separate, at times there were measurable concentrations of bromoform in the control systems. However, as soon as use of bromoform in the other systems was stopped, it disappeared from the controls. Apparentiy, there was sufficient bromoform vapor present in the air to allow some to enter the control exposure systems. The post exposure data, however, indicate that the water and tissue levels of bromoform return to zero and remain there. Therefore, the controls in these tests are actually serving as low-concentration exposure systems. The data for the period after bromoform introduction was stopped show that water concentrations and tissue concentrations returned to zero. This does not provide the classical control condition but serves a a strong indication that if a completely separate system in another laboratory room had been used, the control levels would have stayed at zero. 
The average water concentration during the 28-day exposure of menhaden in the control system was $0.03 \mathrm{mg}$ bromoform/l, a concentration not different from the $0.1 \mathrm{mg}$ bromoform/ $\ell$ target test condition average of $0.04 \mathrm{mg}$ bromoform $/ \ell$. The 5 ame was true for the menhaden exposures where the control average bromoform concentrations was $0.04 \mathrm{mg} / \ell$ and the $0.1 \mathrm{mg} / \ell$ target was $0.05 \mathrm{mg} / \ell$.

These data indicate that bromoform is taken up by these species, but that the degree of concentration depends on the individual, the species and the water concentrations. For molluscs, the general trend is for the tissue concentrations to reflect the water concentrations. Menhaden and shrimp, however, show a tendency to concentrate bromoform by a factor of 3-50 above ambient water concentrations. However, there are also indications that at water concentrations above $0.1 \mathrm{mg} / \ell$, the body burdens decrease with time to approximately $0.4 \mu \mathrm{g} / \mathrm{g} \mathrm{tissue,} \mathrm{a} \mathrm{body}$ burden concentration similar to that found in organisms exposed to lower water concentrations.

Testing for bioaccumulation of bromoform is very difficult because of the problem associated with providing a precise concentration of bromoform in water for the 28-day exposure period. In addition, there are problems of vapor contamination of the control systems if the two are operated in the same room. However, the results of the tests presented here indicate that for the molluscs tested, the tissue concentrations will be a reflection of the ambient water concentrations, and that menhaden and shrimp will concentrate bromoform up to a point, after which there appears to be a maximum body burden that is maintained with time. Further testing is needed to determine where within the organism the bromoform is concentrated and the factors that influence its uptake.

\section{CONCLUSIONS AND RECOMMENDATIONS}

The toxicity tests conducted indicate that for brown shrimp the calculated $96-\mathrm{hr}$ LC50 is $26 \mathrm{mg} / \ell$ with a $95 \%$ confidence interval between 33 and 20 $\mathrm{mg} / \ell$.

The 96-hr LC50 concentration for menhaden was calculated to be $12 \mathrm{mg} / \ell$ with a 95\% confidence interval between $15 \mathrm{mg} / \ell$ and $9 \mathrm{mg} / \ell$.

Behavioral changes were observed in both menhaden and shrimp exposed to sublethal concentrations of bromoform.

Standard 96-hr LC50 values were not calculated for littleneck clams, quahogs or Eastern oysters. Based on latent mortalities and mortalities in the 28-day uptake exposures, it is estimated that the 96-hr LC50 value would be greater than 30 to $40 \mathrm{mg} / \ell$. 
All the tested species rapidly took up and depurated bromoform. The mollusk species had tissue concentrations that were above water concentrations during the first week of exposure, but the tissue concentration decreased during the last three weeks of exposure and were reflective of the ambient water concentrations.

In shrimp and menhaden the tissue concentrations were also highest during the first week of exposure. After that they fell to a concentration of approximately $0.4 \mu \mathrm{g} / \mathrm{g}$ and remained there for the remaining three weeks of exposure. The tissue concentrations of $0.4 \mu \mathrm{g} / \mathrm{g}$ appear to be maintained independent of the water concentration.

The 96-hr LC50 values and estimated LC50 values indicate that relatively large amounts of bromoform would need to be generated in power plant discharges to cause acute toxicities.

The extent and consequences of the behavioral changes noted on the survival of the shrimp and menhaden are not known.

The bromoform uptake data indicates that if bromoform is present in the water, it will be present in the tissue of the organism.

Further investigations would be required to refine the LC50 values and to determine the major factors that determine the extent to which bromoform is bioaccumulated. 


\section{REFERENCES}

Bean, R.M., R.G. Riley, and P.W. Ryan. 1978. Investigations of halogenated components formed from chlorination of marine water. In: Water Chlorination--Environmental Impact and Health Effects, Vol. 2, pp. 223-234 (R.L. Jolley, H. Gorchev, D.H. Hamilton, Jr., ed.). Ann Arbor Science, Ann Arbor, Mich.

Bean, R.M., D.C. Mann, and R.G. Riley. 1980. Analyses of organohalogen products from chlorination of natural waters under simulated biofouling control conditions. NUREG/CR-1301, U.S. Nuclear Regulatory Commission, Washington, D.C. *

Carpenter, J.H. and C.A. Smith. 1978. Reactions in chlorinated sea water. In: Water Chlorination--Environmental Impact and Health Effects, $\bar{V}_{01}$. 2, pp. 195-208. (R.L. Jolley, H. Gorchev, D.H. Hamilton, Jr., ed.). Ann Arbor Science, Ann Arbor, Mich.

Litchfield, J.T., Jr. and F.W. Wilcoxon. 1949. A simplified method of evaluating dose-effect experiments. J. Pharmacol. Exp. Theraput. 96:99-113.

Roberts, M.H., Jr., R.J. Diaz, M.E. Bender, and R.J. Hugget. 1975. Acute toxicity of chlorine to selected estuarine species. J. Fish.Res. Bd. Canada 32:2525-2528.

Scott, G.I. and D.P. Middaugh. 1978. Seasonal chronic toxicity of chlorination to the American oyster, Crassostrea virginica (G). In: Water Chlorination Environmental Impact and Health Effects, Vol. 2 . pp. 341-350. (R. L. Jolley, H. Gorchev, D.H. Hamilton, Jr., ed.). Ann Arbor Science, Ann Arbor, Mich.

Thatcher, T.0. 1978. The relative sensitivity of Pacific Northwest fishes and invertebrates to chlorinated sea water. In: Water Chlorination--Environmental Impact and Health Effects. $\overline{\text { ol. } 2}$. pp. 341-350. (R.L. Jolley, H. Gorchev, D.H. Hamilton, Jr., ed.). Ann Arbor Science, Ann Arbor, Mich.

\footnotetext{
*Available for purchase from the ARC/GP0 Sales Program, U.S. Nuclear Regulatory Commission, Washington, DC 20555, and the National Technical Information Service, Springfield, VA 22161.
} 
Table 1. Concentration of bromoform $(\mathrm{mg} / \mathrm{\ell})$ in tank at time of noted clam responses.

slight retraction of siphon

Retraction, then extension by one clam

Al1 siphons retracted
$430 \mathrm{mg} / \mathrm{\ell}$

$425 \mathrm{mg} / \ell$

$346 \mathrm{mg} / \mathrm{l}$ 
Table 2. Measured Bromoform Concentrations $(\mathrm{mg} / \mathrm{l})$ in Protothaca staminea in Exposure Tanks

\begin{tabular}{|c|c|c|c|c|}
\hline DATE & 1 & $\begin{array}{r}\text { TARGET } \\
5\end{array}$ & $\begin{array}{c}\text { RATION } \\
10\end{array}$ & 20 \\
\hline $5 / 30 / 78$ & 1.9 & 4.8 & 8.4 & 11.8 \\
\hline $5 / 31 / 78$ & 2.3 & 4.2 & 14.0 & 27.1 \\
\hline $6 / 1 / 78(\text { Surface })^{\star}$ & 4.8 & 7.5 & 21.7 & 45.8 \\
\hline $6 / 1 / 78(\text { Bottom })^{\star}$ & 4.4 & 10.2 & 20.1 & 48.3 \\
\hline $6 / 2 / 78$ & 6.5 & 11.2 & 30.6 & 57.2 \\
\hline $6 / 5 / 78$ & 1.7 & 6.5 & 20.8 & 30.2 \\
\hline $6 / 6 / 78$ & 1.4 & 4.9 & 17.4 & 29.6 \\
\hline $6 / 7 / 78$ & 1.1 & 5.3 & 24.9 & 21.7 \\
\hline $6 / 8 / 78$ & 0.6 & 3.8 & 17.0 & 17.7 \\
\hline $6 / 9 / 78$ & 0.9 & 4.9 & 23.0 & 9.0 \\
\hline $6 / 12 / 78$ & 1.0 & 4.5 & 20.0 & 10.8 \\
\hline $6 / 13 / 78$ & 0.9 & 11.7 & 36.3 & 16.7 \\
\hline $6 / 14 / 78$ & 0.6 & 4.0 & 18.6 & 15.3 \\
\hline $6 / 15 / 78$ & 0.9 & 5.7 & 15.1 & 12.3 \\
\hline $6 / 16 / 78$ & 1.1 & 14.9 & 15.0 & 20.6 \\
\hline $6 / 19 / 78$ & 0.7 & 5.1 & 15.5 & 76.6 \\
\hline $6 / 20 / 78$ & 0.8 & 6.1 & 16.3 & 45.9 \\
\hline $6 / 21 / 78$ & 0.9 & 6.4 & 22.8 & 22.2 \\
\hline $6 / 22 / 78$ & 0.7 & 6.7 & 15.9 & 20.6 \\
\hline $6 / 23 / 78$ & 1.0 & 10.8 & 17.6 & 18.2 \\
\hline $6 / 26 / 78$ & 0.4 & 8.0 & 16.4 & 14.6 \\
\hline $6 / 27 / 78$ & 0.5 & 8.2 & 18.7 & 23.0 \\
\hline
\end{tabular}

* Duplicate samples collected; surface sample by routine procedure, bottom samples by use of glass siphon with opening drawing sample from $5 \mathrm{~cm}$ above bottom. 
Table 3. Bromoform Concentration in Each Test Organism for Eastern Oyster (Crassostrea virginica) ( $\mu \mathrm{g} / \mathrm{g}$ tissue-wet weight)

Average Bromoform

$$
\text { Exposure }
$$

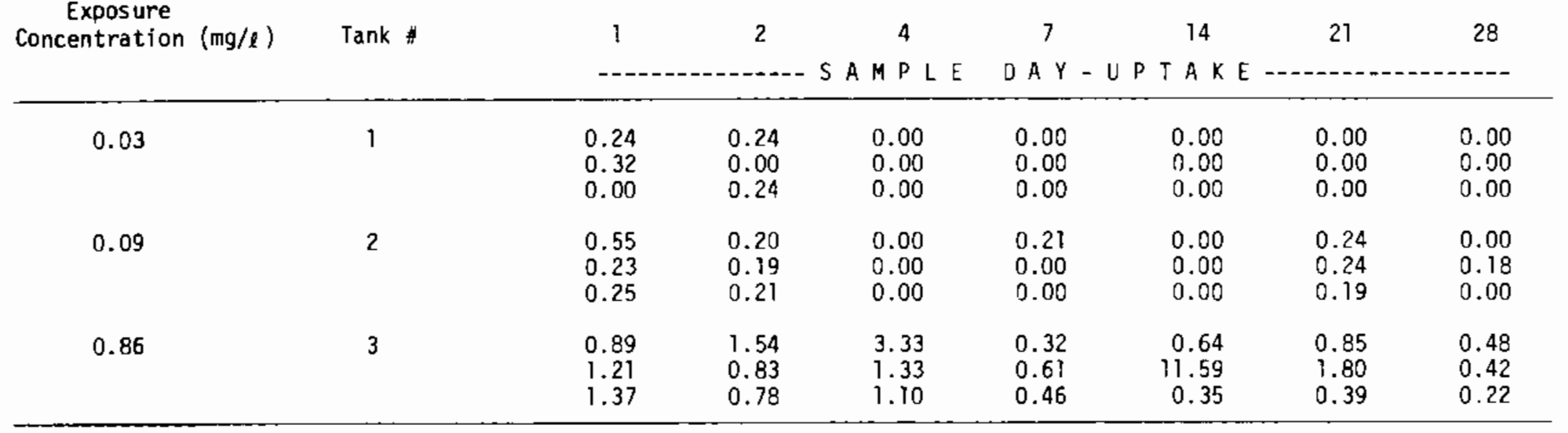

\begin{tabular}{|c|c|c|c|c|c|c|c|c|}
\hline \multirow[t]{2}{*}{$\begin{array}{l}\text { Average Bromoform } \\
\text { Exposure } \\
\text { Concentration }(\mathrm{mg} / \mathrm{l})\end{array}$} & \multirow[t]{2}{*}{ Tank \# } & \multirow{2}{*}{$\begin{array}{c}1 \\
-\end{array}$} & $\begin{array}{c}2 \\
-5\end{array}$ & 4 & 7 & 14 & \multirow{2}{*}{$\begin{array}{c}21 \\
-\end{array}$} & \multirow{2}{*}{$\begin{array}{c}28 \\
-\end{array}$} \\
\hline & & & $-S$ & L. E & $D A Y-D$ & R A T & & \\
\hline 0.00 & 1 & $\begin{array}{l}0.00 \\
0.00 \\
0.00\end{array}$ & $\begin{array}{l}0.00 \\
0.00 \\
0.00\end{array}$ & $\begin{array}{l}0.00 \\
0.00 \\
0.00\end{array}$ & $\begin{array}{l}0.00 \\
0.00 \\
0.00\end{array}$ & $\begin{array}{l}0.00 \\
0.00 \\
0.00\end{array}$ & $\begin{array}{l}0.00 \\
0.00 \\
0.00\end{array}$ & $\begin{array}{l}0.00 \\
0.00 \\
0.00\end{array}$ \\
\hline 0.00 & 2 & $\begin{array}{l}0.00 \\
0.00 \\
0.00\end{array}$ & $\begin{array}{l}0.00 \\
0.00 \\
0.00\end{array}$ & $\begin{array}{l}0.00 \\
0.00 \\
0.00\end{array}$ & $\begin{array}{l}0.00 \\
0.00 \\
0.00\end{array}$ & $\begin{array}{l}0.00 \\
0.00 \\
0.00\end{array}$ & $\begin{array}{l}0.00 \\
0.00 \\
0.00\end{array}$ & $\begin{array}{l}0.00 \\
0.00 \\
0.00\end{array}$ \\
\hline 0.00 & 3 & $\begin{array}{l}0.00 \\
0.00 \\
0.00\end{array}$ & $\begin{array}{l}0.00 \\
0.00 \\
0.00\end{array}$ & $\begin{array}{l}0.00 \\
0.00 \\
0.00\end{array}$ & $\begin{array}{l}0.00 \\
0.00 \\
0.00\end{array}$ & $\begin{array}{l}0.00 \\
0.00 \\
0.00\end{array}$ & $\begin{array}{l}0.00 \\
0.00 \\
0.00\end{array}$ & $\begin{array}{l}0.00 \\
0.00 \\
0.00\end{array}$ \\
\hline
\end{tabular}


Table 4. Bromoform Concentration in Each Test Organism for Quahaug (Mercenaria mercenaria) ( $\mu \mathrm{g} / \mathrm{g}$ tissue-wet weight)

Average Bromoform

$$
\text { Exposure }
$$

$$
\text { Concentration }(\mathrm{mg} / \mathrm{l})
$$

Tank \#

1

24

7

14

21

28

\begin{tabular}{|c|c|c|c|c|c|c|c|c|}
\hline 0.03 & 1 & $\begin{array}{l}0.11 \\
0.11 \\
0.08\end{array}$ & $\begin{array}{l}0.04 \\
0.07 \\
0.05\end{array}$ & $\begin{array}{l}0.12 \\
0.00 \\
0.07\end{array}$ & $\begin{array}{l}0.08 \\
0.07 \\
0.08\end{array}$ & $\begin{array}{l}0.06 \\
0.07 \\
0.00\end{array}$ & + & $\begin{array}{l}0.03 \\
0.00 \\
0.00\end{array}$ \\
\hline 0.09 & 2 & $\begin{array}{l}0.46 \\
0.42 \\
0.50\end{array}$ & $\begin{array}{l}0.09 \\
0.15 \\
0.15\end{array}$ & $\begin{array}{l}0.10 \\
0.09 \\
0.07\end{array}$ & $\begin{array}{l}0.09 \\
0.08 \\
0.08\end{array}$ & $\begin{array}{l}0.00 \\
0.07 \\
0.22\end{array}$ & $\begin{array}{l}0.17 \\
0.15 \\
0.73\end{array}$ & $\begin{array}{l}1.87 \\
0.25 \\
0.23\end{array}$ \\
\hline 0.99 & 3 & $\begin{array}{l}0.11 \\
0.06 \\
0.17\end{array}$ & $\begin{array}{l}0.24 \\
0.14 \\
0.15\end{array}$ & $\begin{array}{l}0.72 \\
1.01 \\
1.28\end{array}$ & $\begin{array}{l}0.61 \\
0.33 \\
0.40\end{array}$ & $\begin{array}{l}0.28 \\
0.31 \\
0.19\end{array}$ & $\begin{array}{l}0.48 \\
0.70 \\
0.34\end{array}$ & $\begin{array}{l}0.09 \\
0.21 \\
0.15\end{array}$ \\
\hline
\end{tabular}
- SAMPLE DAY - UPTAKE

\section{Average Bromoform

\begin{tabular}{|c|c|c|c|c|c|c|c|c|}
\hline $\begin{array}{l}\text { Exposure } \\
\text { Concentration }(\mathrm{mg} / \mathrm{l})\end{array}$ & Tank \# & 1 & 2 & 4 & 7 & 14 & 21 & 28 \\
\hline & & --- & $-\ldots-5$ & $P L E$ & $D A Y-D$ & R A T & -- & - \\
\hline 0.00 & 1 & $\begin{array}{l}0.00 \\
0.00 \\
0.00\end{array}$ & + & $\begin{array}{r}1.83 \\
106.96 \\
0.00\end{array}$ & $\begin{array}{l}0.00 \\
0.00 \\
0.00\end{array}$ & $\begin{array}{l}0.00 \\
0.00 \\
0.00\end{array}$ & $\begin{array}{l}0.00 \\
0.00 \\
0.00\end{array}$ & $\begin{array}{l}0.00 \\
0.00 \\
0.00\end{array}$ \\
\hline 0.00 & 2 & $\begin{array}{l}0.00 \\
0.00 \\
0.16\end{array}$ & $\begin{array}{l}0.00 \\
0.13 \\
0.40\end{array}$ & $\star$ & $\begin{array}{l}0.00 \\
0.00 \\
0.00\end{array}$ & $\begin{array}{l}0.00 \\
0.00 \\
0.00\end{array}$ & $\begin{array}{l}0.00 \\
0.00 \\
0.00\end{array}$ & $\begin{array}{l}0.00 \\
0.00 \\
0.00\end{array}$ \\
\hline 0.00 & 3 & $\begin{array}{l}0.00 \\
0.00 \\
0.17\end{array}$ & $\begin{array}{l}0.00 \\
0.00 \\
0.00\end{array}$ & $\begin{array}{l}0.00 \\
0.00 \\
0.00\end{array}$ & $\begin{array}{l}0.00 \\
0.00 \\
0.00\end{array}$ & $\begin{array}{l}0.00 \\
0.00 \\
0.00\end{array}$ & $\begin{array}{l}0.00 \\
0.00 \\
0.00\end{array}$ & + \\
\hline
\end{tabular} \\ Exposure}

+ No data-sample lost

* No organisms remaining due to earlier mortality 
Table 5. Average $(\bar{x})$ Body Burden and Standard Deviation (S.D.) for Littleneck Clam (Protothaca staminea ( $\mu \mathrm{g} / \mathrm{g}$ tissue-wet weight)

\begin{tabular}{|c|c|c|c|c|c|c|c|c|c|}
\hline & & & & UPTAKE & & & & & \\
\hline $\begin{array}{l}\text { Average Bromoform } \\
\text { Exposure }\end{array}$ & & & 1 & 2 & 4 & 7 & 14 & 21 & 28 \\
\hline Concentration & Tank \# & & ...-- & $--\ldots-n$ & $\ldots S A$ & $P L E$ & $D A Y \ldots$ & $\ldots$ & -...... \\
\hline $0 \mathrm{mg} / \ell$ & 1 & $\bar{x}$ & .03 & .15 & .13 & 0 & .50 & .01 & .04 \\
\hline & & S.D. & \pm .03 & \pm .17 & \pm .08 & & \pm .07 & \pm .02 & \pm .03 \\
\hline $2 \mathrm{mg} / \mathrm{l}$ & 2 & $\bar{x}$ & 9.94 & 5.59 & 13.65 & 4.08 & 2.22 & 2.05 & 1.08 \\
\hline & & S.D. & \pm 2.16 & \pm 1.38 & $\pm 4.8 \mathrm{I}$ & \pm .67 & \pm 1.05 & \pm .40 & \pm .18 \\
\hline $19 \mathrm{mg} / \mathrm{l}$ & 3 & $\bar{x}$ & 22.14 & 17.63 & 38.05 & 37.29 & 22.05 & 24.85 & 14.25 \\
\hline & & S.D. & \pm 4.58 & \pm 2.30 & \pm 6.35 & \pm 7.14 & \pm 3.35 & \pm 7.90 & \pm 7.32 \\
\hline & & & & DEPURATI & & & & & \\
\hline $\begin{array}{l}\text { Average Bromoform } \\
\text { Exposure }\end{array}$ & & & 1 & 2 & 4 & 7 & 14 & 21 & 28 \\
\hline Concentration & Tank $\sharp$ & & $\cdots$ & - & $\cdots S A$ & $P L E$ & DAY $\cdots$ & $\cdots$ & (n- \\
\hline $0 \mathrm{mg} / \mathrm{t}$ & 1 & $\tilde{x}$ & 0 & 0 & 0 & 0 & 0 & 0 & 0 \\
\hline $0 \mathrm{mg} / \mathrm{f}$ & 2 & $\vec{x}$ & .12 & .03 & 0 & .02 & 0 & 0 & 0 \\
\hline & & S.D. & \pm .26 & \pm .03 & & \pm .02 & & & \\
\hline $0 \mathrm{mg} / \ell$ & 3 & $\bar{x}$ & 5.28 & $0.33^{\star}$ & 0 & 0 & 0 & .17 & 0 \\
\hline & & 5.0 & \pm 4.81 & 0.30 & 0 & 0 & 0 & \pm .02 & \\
\hline * Range -2 values & only & & & & & & & & \\
\hline
\end{tabular}


Table 6. Bromoform Concentration in Each Test Organism for Menhaden (Brevoortia tyrannus) ( $\mu \mathrm{g} / \mathrm{g}$ tissue-wet weight)

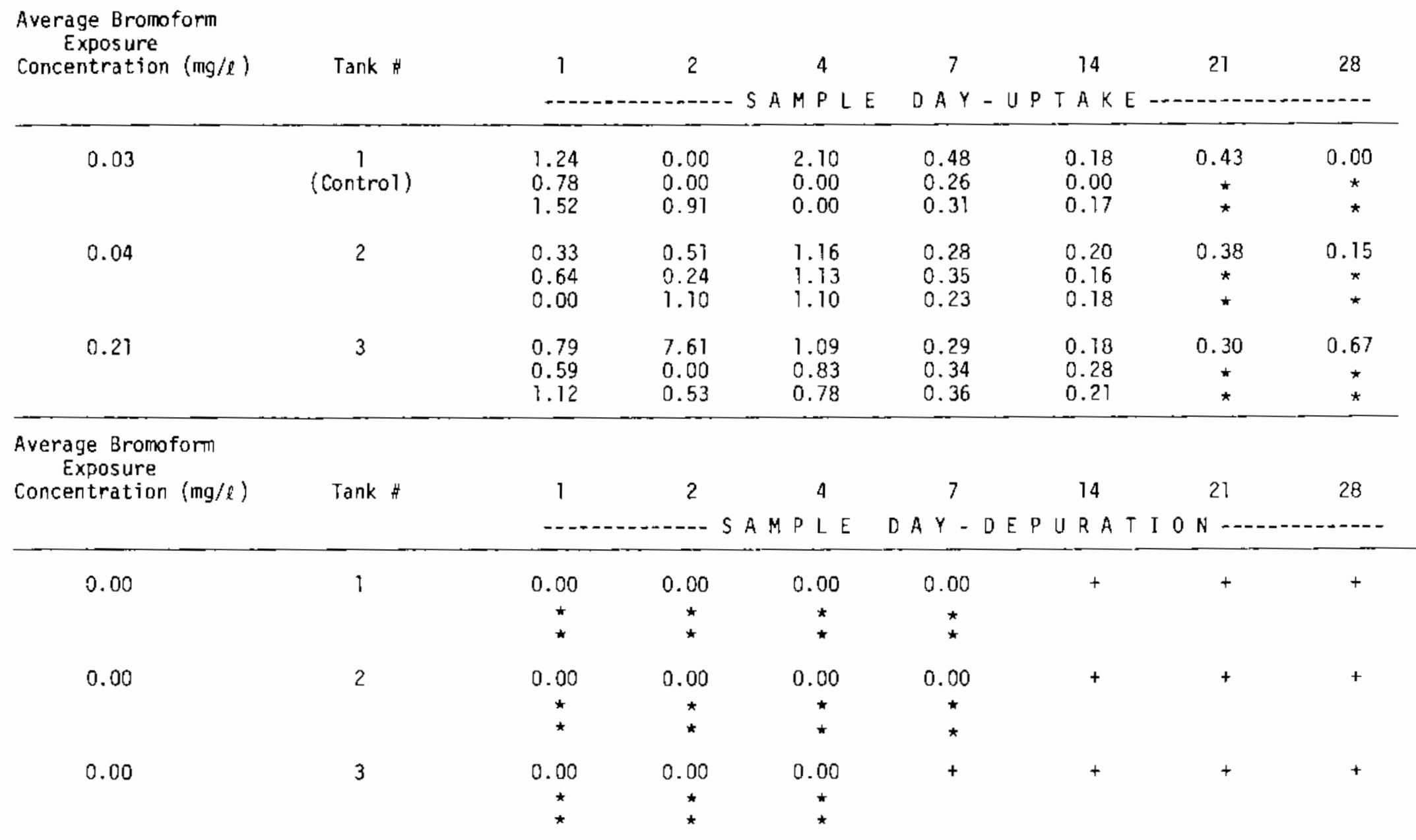

+ No data

* No organisms remaining due to earlier mortality 
Tab1e 7. Bromoform Concentration in Each Test Organism for Shrimp (Penaeus aztecus) ( $\mu \mathrm{g} / \mathrm{g}$ tissue-wet weight)

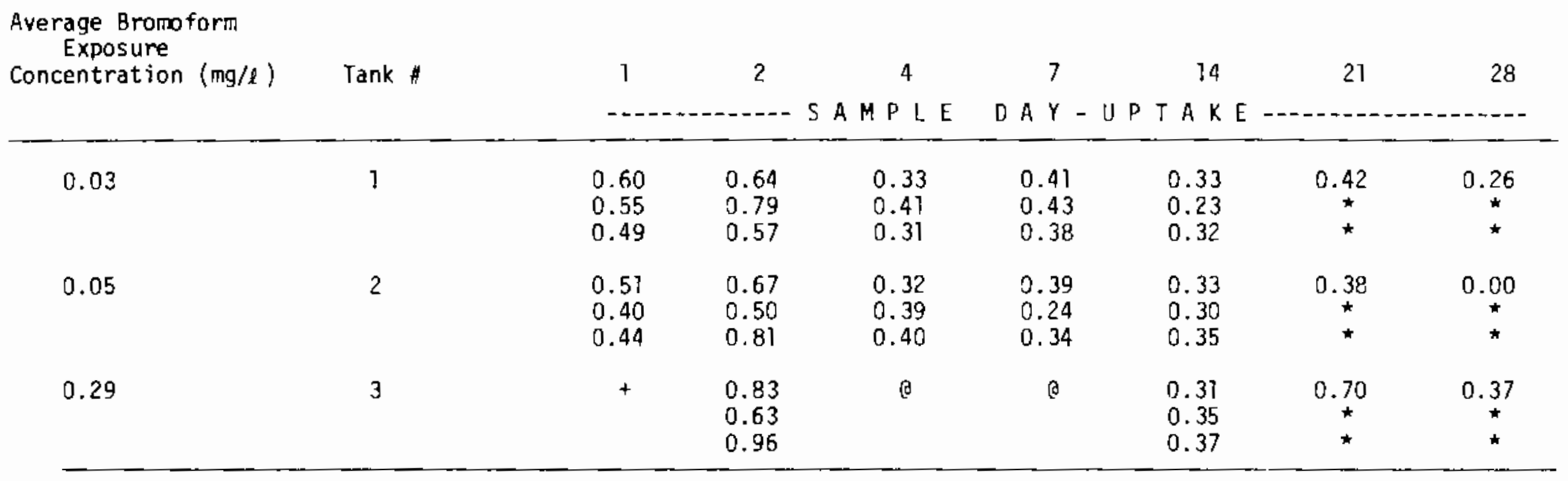

Average Bromoform

$$
\text { Exposure }
$$

\begin{tabular}{|c|c|c|c|c|c|c|c|c|}
\hline Concentration $(\mathrm{mg} / \mathrm{l})$ & Tank \# & $\begin{array}{c}1 \\
-\cdots\end{array}$ & 2 & $M P^{4} L E$ & DA $\begin{array}{l}7 \\
Y\end{array}$ & $P U^{14}$ & $0^{21}-$ & 28 \\
\hline 0.00 & 1 & $\begin{array}{c}0.00 \\
\star \\
\star\end{array}$ & $\begin{array}{c}0.00 \\
\star \\
\star\end{array}$ & $\begin{array}{c}0.00 \\
\star \\
\star\end{array}$ & $\begin{array}{l}0.00 \\
0.00 \\
\star\end{array}$ & $\begin{array}{l}0.15 \\
0.00 \\
\star\end{array}$ & $\begin{array}{l}0.00 \\
0.00 \\
0.00\end{array}$ & * \\
\hline 0.00 & 2 & 0.00 & 0.00 & 0.00 & $\begin{array}{l}0.00 \\
0.00\end{array}$ & $\begin{array}{l}0.00 \\
0.00 \\
0.00\end{array}$ & $\begin{array}{l}0.00 \\
0.00 \\
0.00\end{array}$ & $\begin{array}{l}0.00 \\
0.00\end{array}$ \\
\hline 0.00 & 3 & 0.00 & 0.00 & 0.00 & 0.00 & $\begin{array}{l}0.00 \\
0.00 \\
\star\end{array}$ & $\begin{array}{c}0.00 \\
0.00 \\
\star\end{array}$ & ॠ \\
\hline
\end{tabular}

a Sample not processed

+ Sample Lost

* No organism remaining due to earlier mortality 


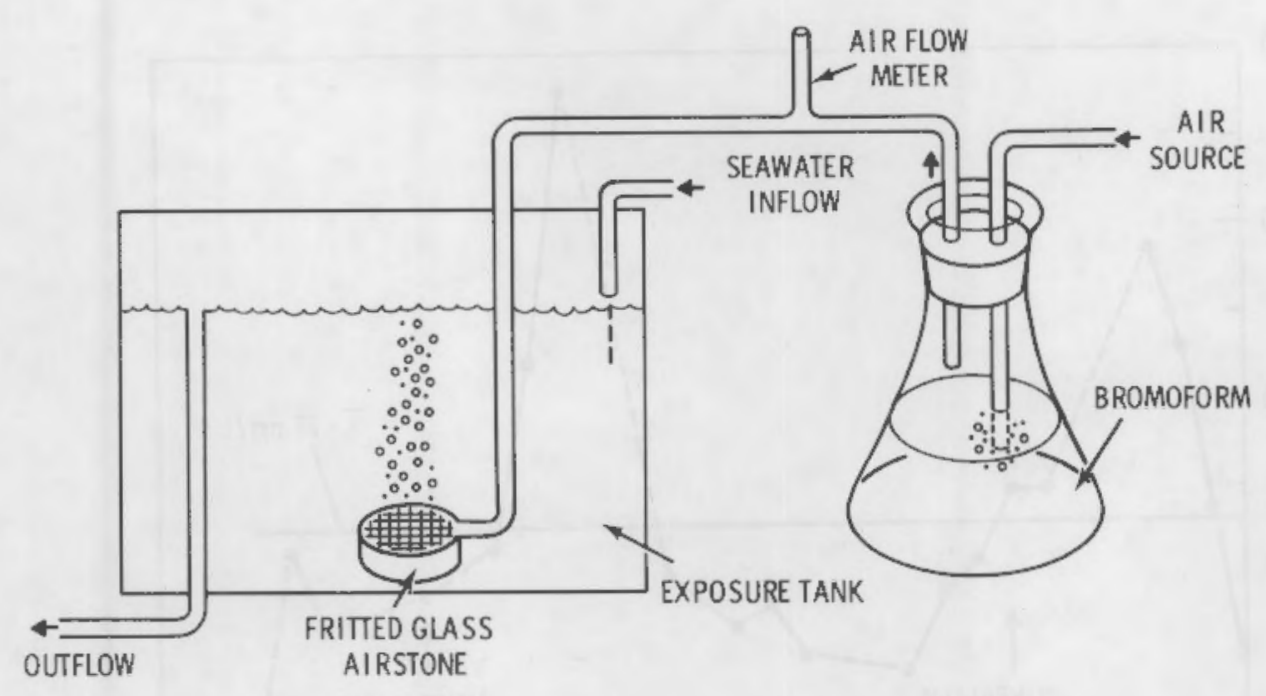

Figure 1. Toxicant delivery system for seawater/bromoform bioassays conducted at Sequim

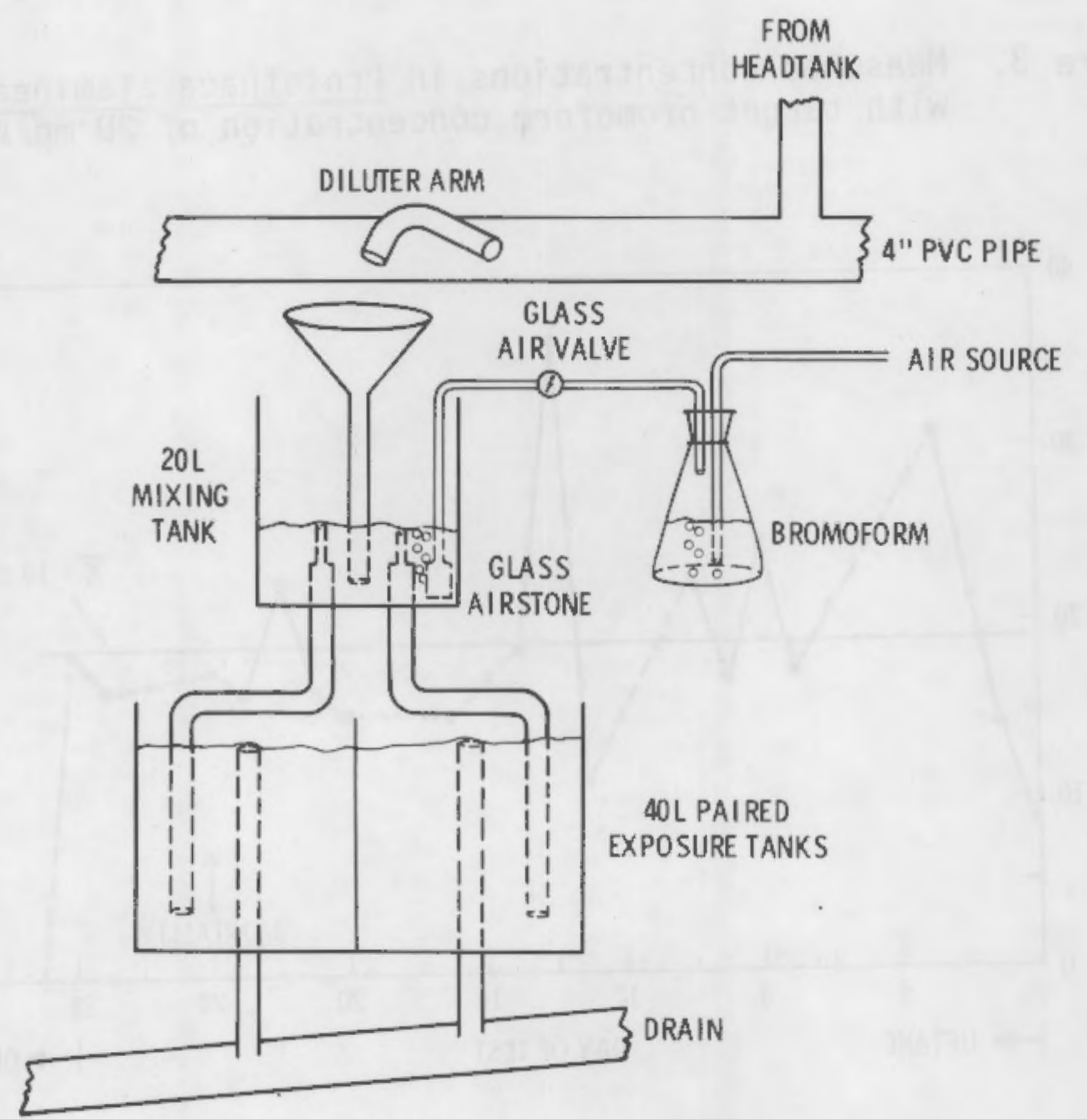

Figure 2. A section of the bromoform exposure system used at the Daytona Beach Laboratory 


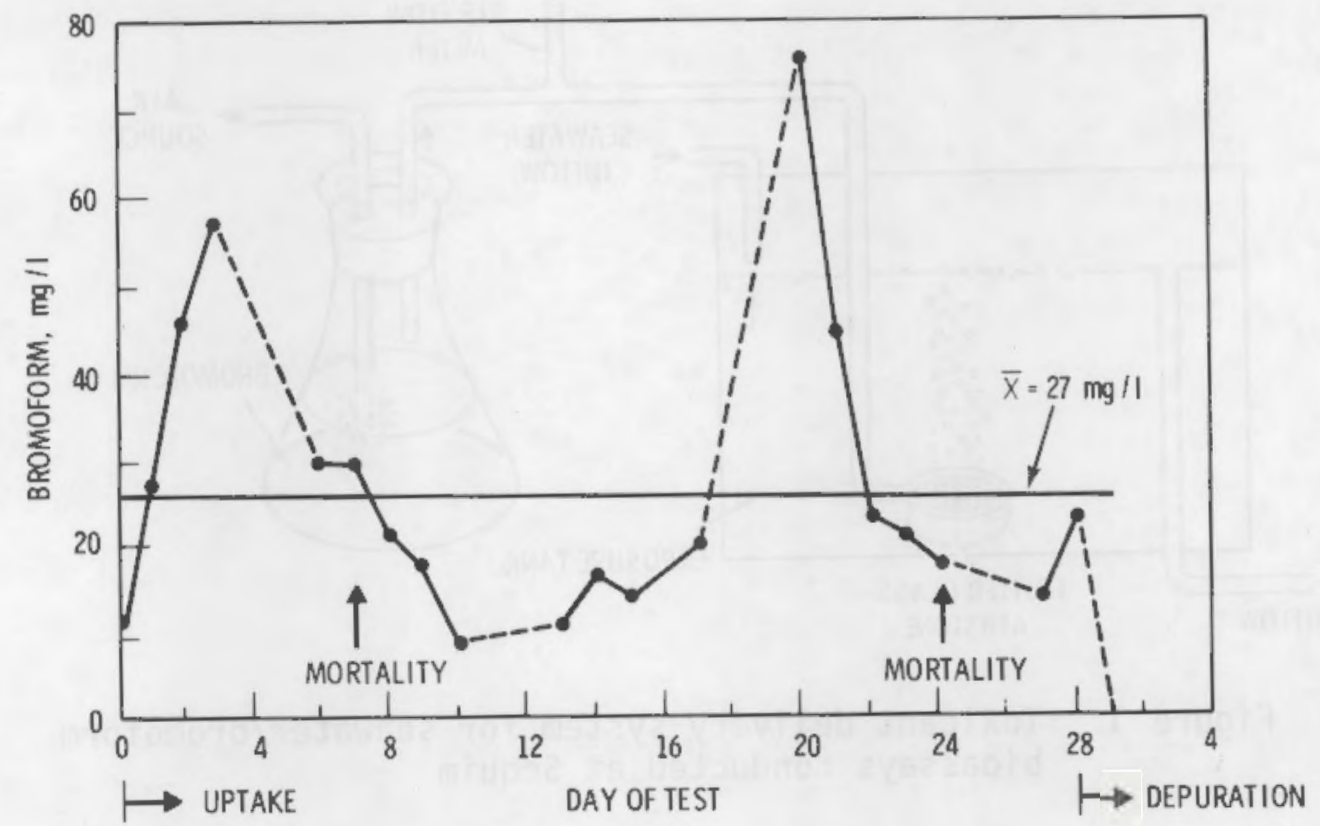

Figure 3. Measured concentrations in Protothaca staminea exposure with target bromoform concentration of $20 \mathrm{mg} / \mathrm{l}$

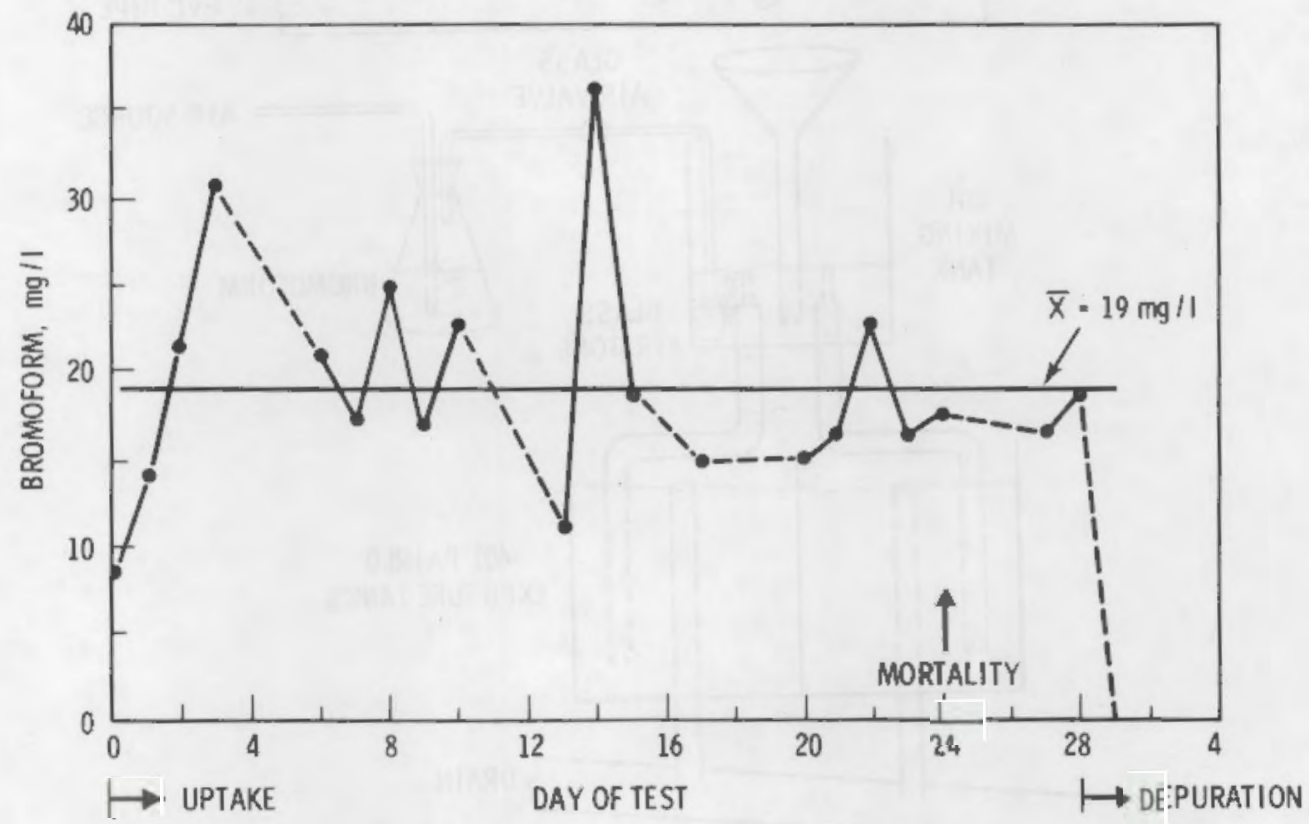

Figure 4. Measured concentrations in Protothaca staminea exposure tank with target bromoform concentration of $10 \mathrm{mg} / \mathrm{\ell}$ 


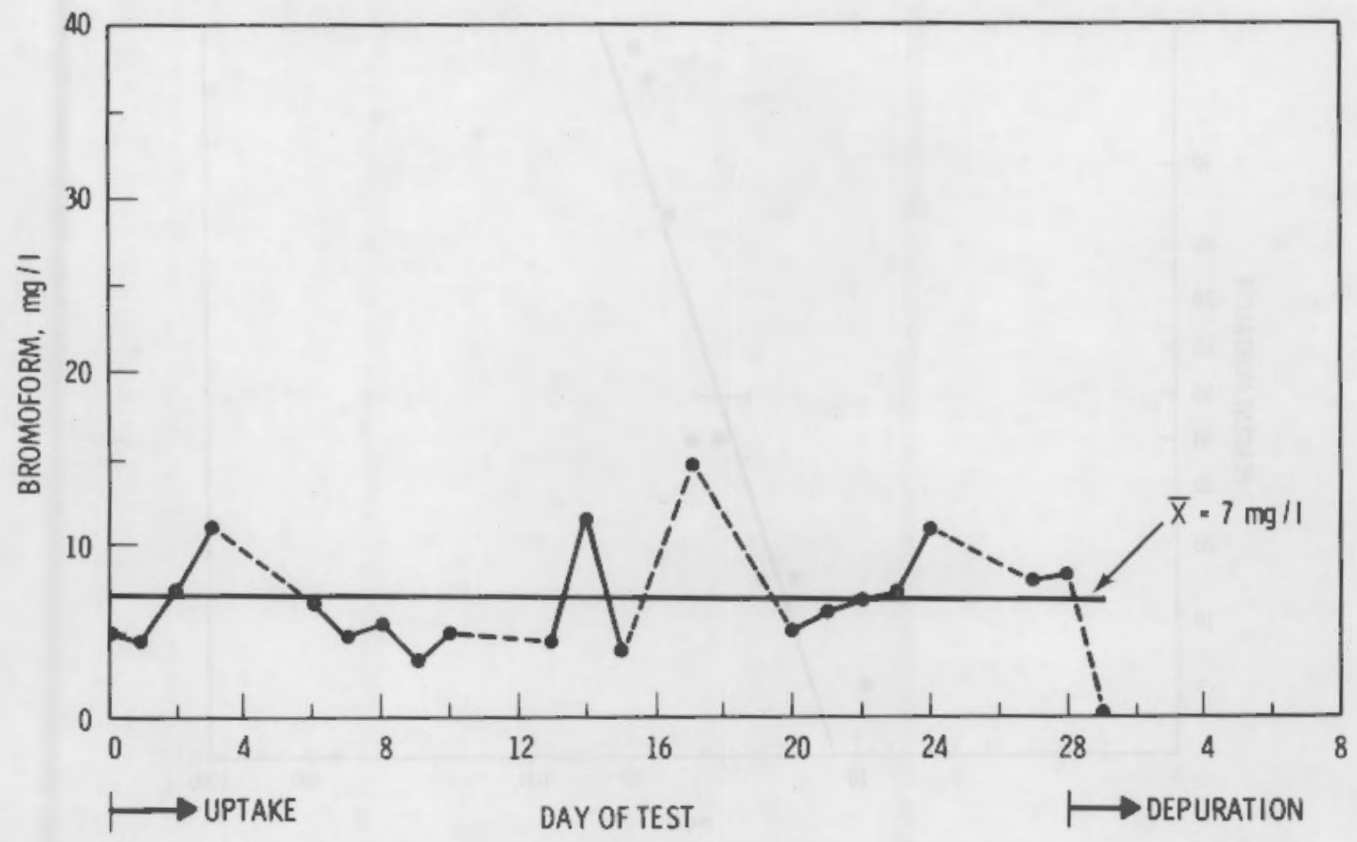

Figure 5. Measured concentrations in Protothaca staminea exposure tank with target bromoform concentration of $5 \mathrm{mg} / \ell$

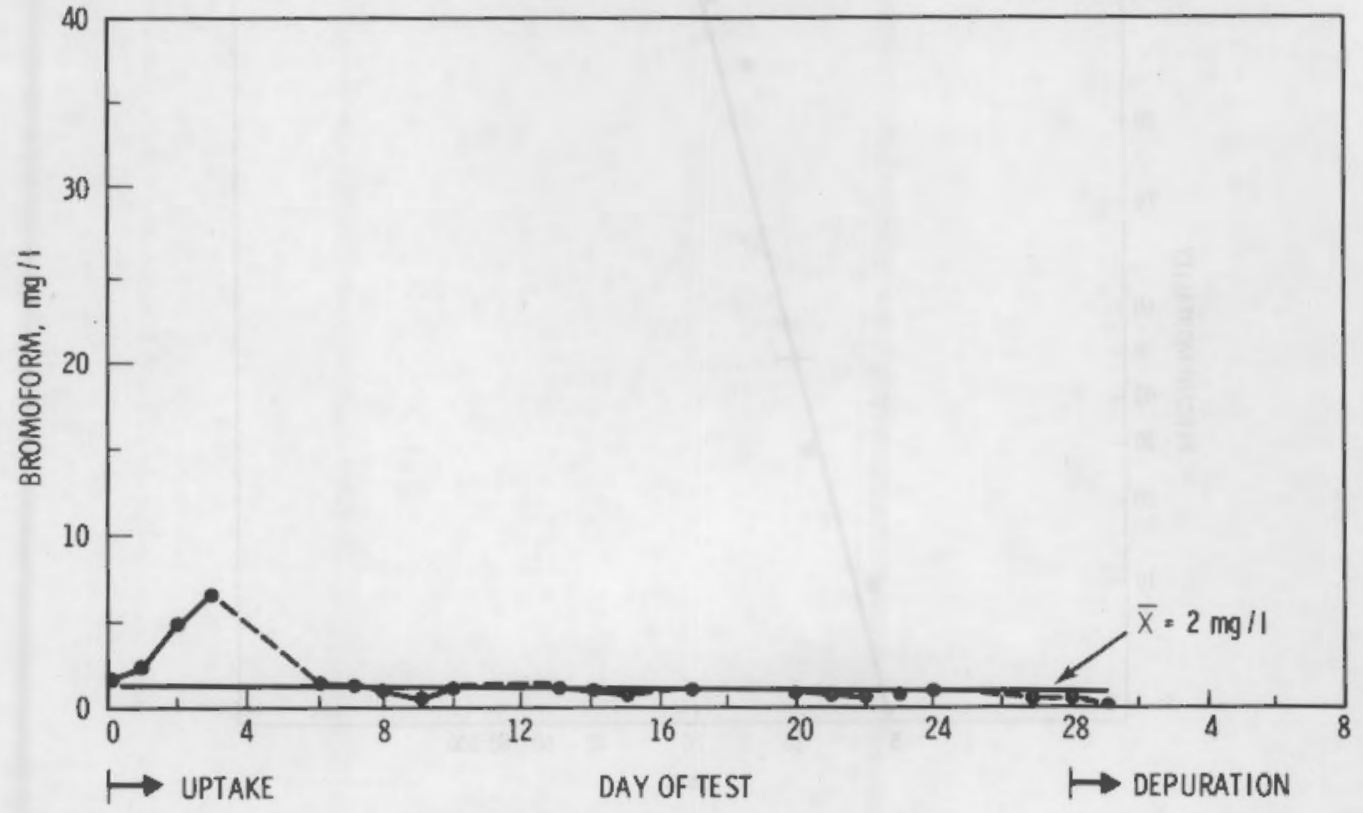

Figure 6. Measured concentrations in Protothaca staminea exposure tank with target bromoform concentration of $1 \mathrm{mg} / \mathrm{l}$ 


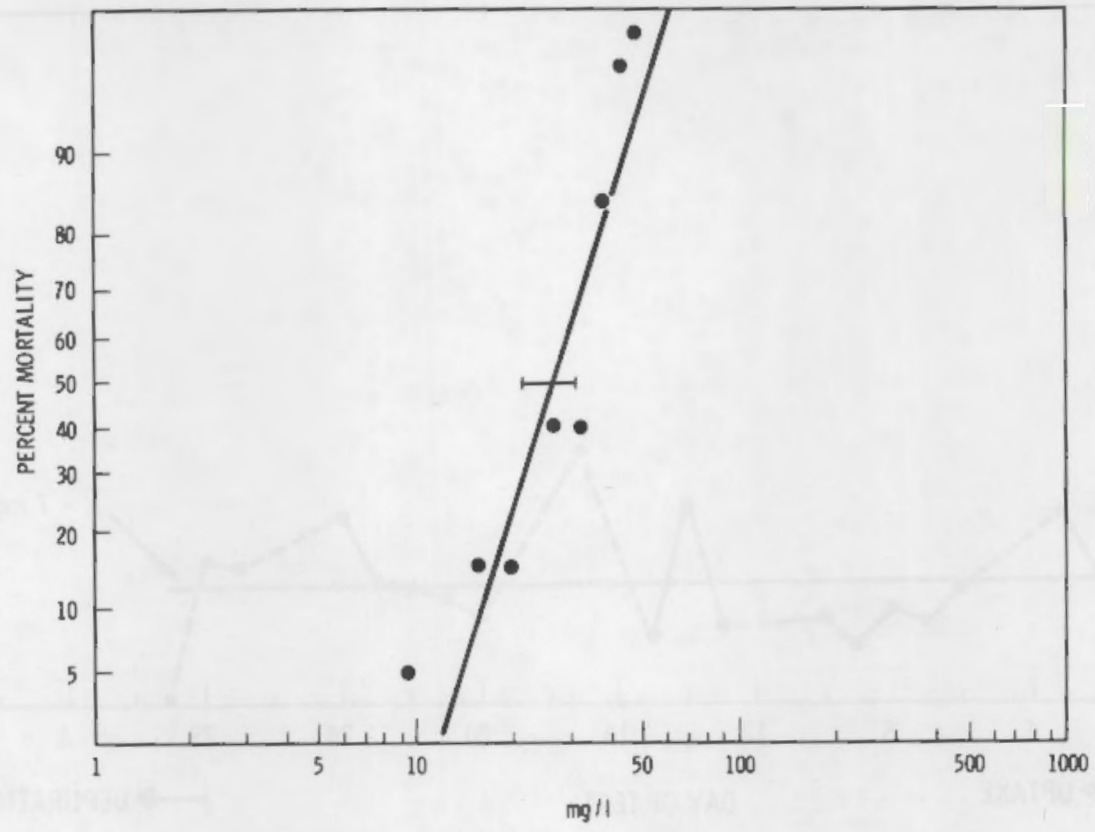

Figure 7. Penaeus aztecus mortality bromoform concentration plot for calculation of 96-hr LC50 by the method of Litchfield and Wilcoxon (1949)

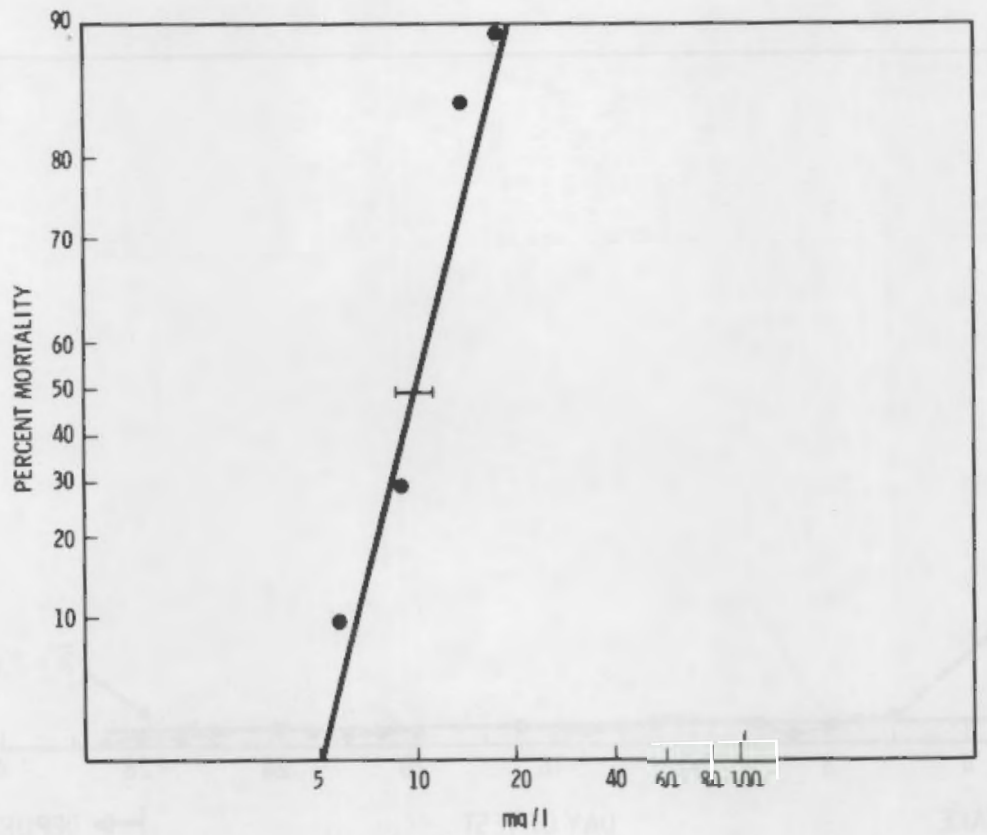

Figure 8. Brevoortia tyrannus mortality bromoform concentration plot for $96-\mathrm{hr}$ LC50 calculation by the method of Litchfield and Wilcoxon (1949) 


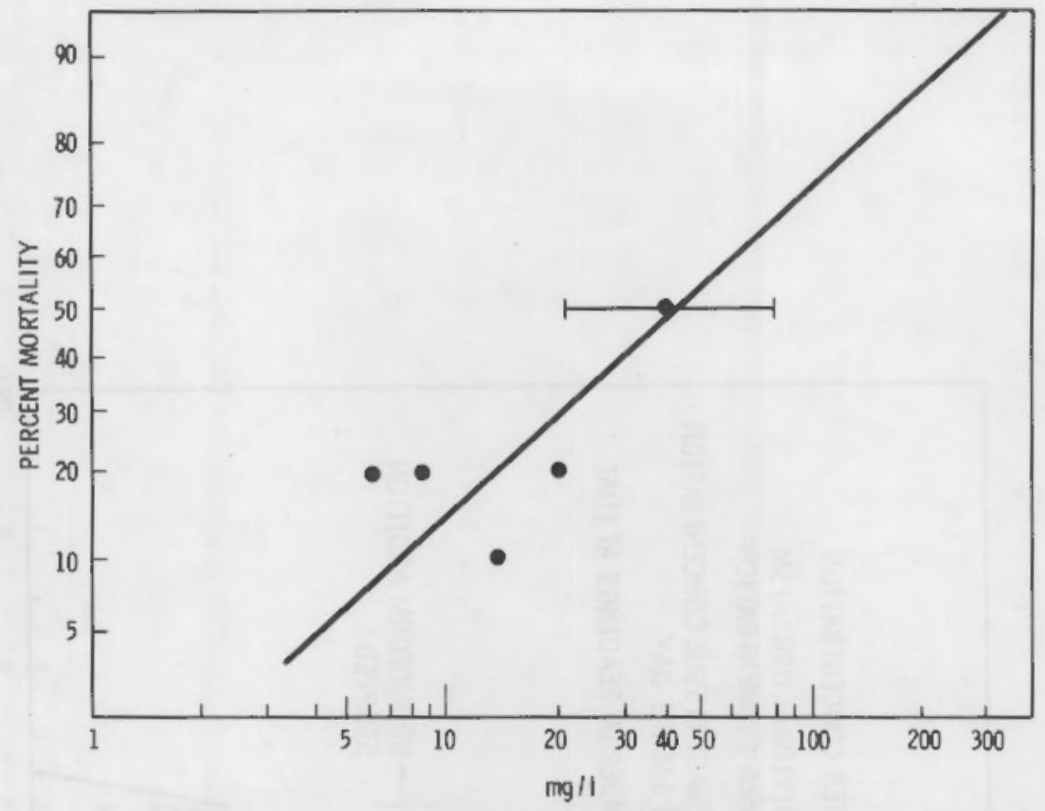

Figure 9. Crassostrea virginica latent mortality bromoform concentration plot used to determine concentration above which the 96-hr LC50 should fall

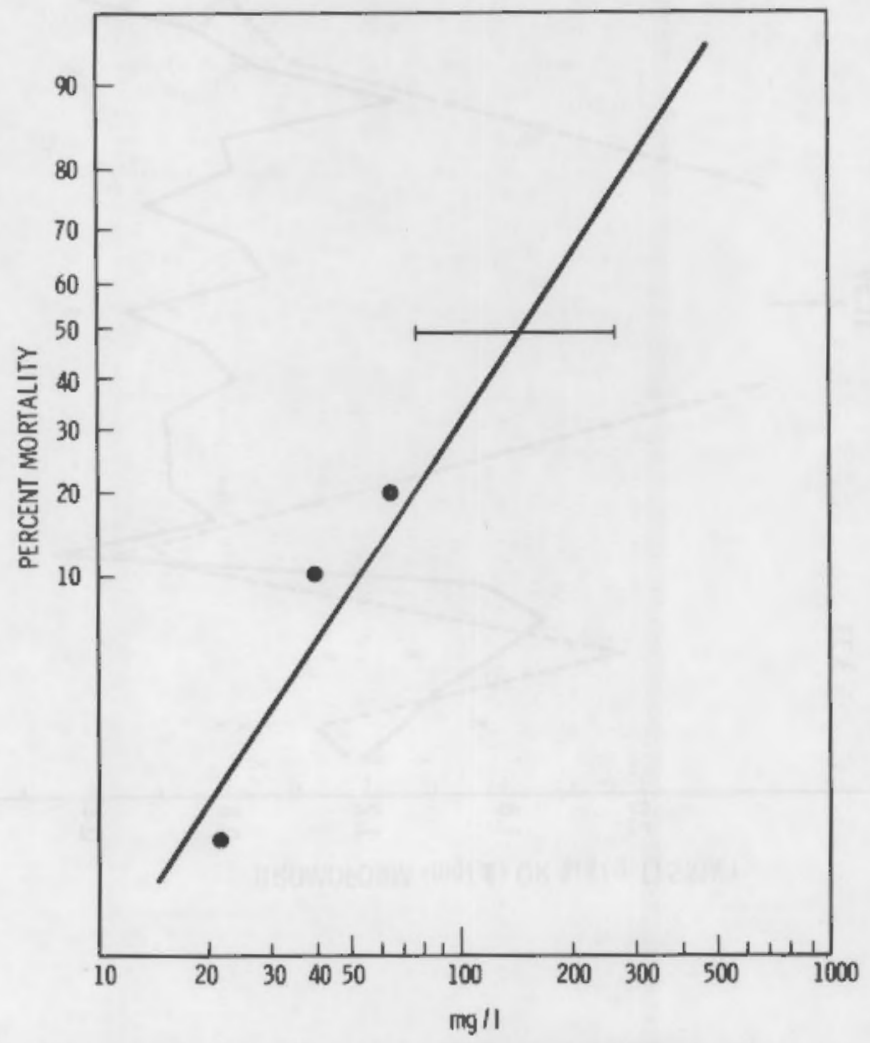

Figure 10. Mercenaria mercenaria latent mortality bromoform concentration plot used to determine concentration above which the 96-hr LC50 should fall 


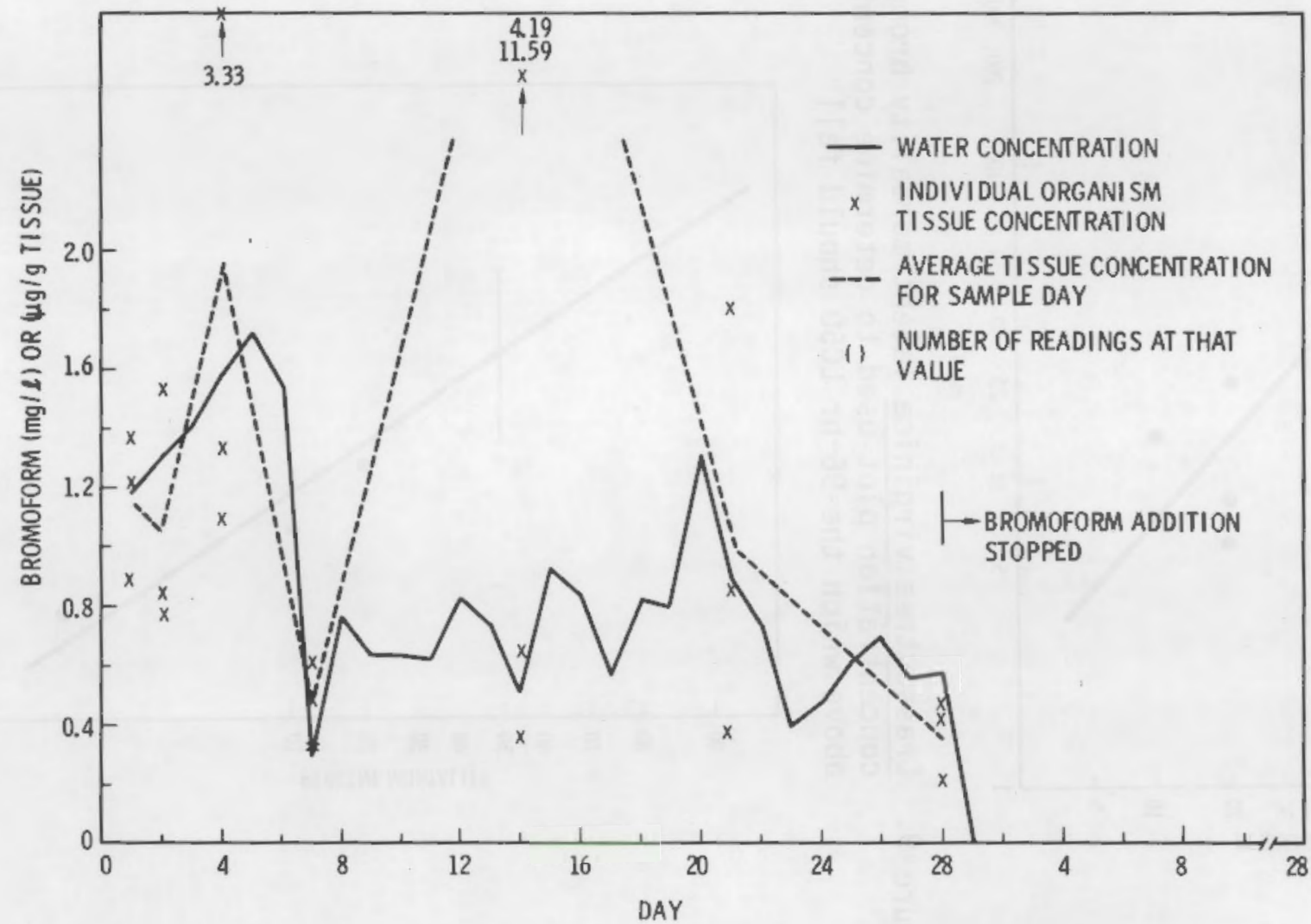

Figure 11. Water and tissue concentrations of bromoform (Eastern oyster, Crassostrea virginica) 28-day uptake/28-day depuration studies. Target water bromoform was $1.0 \mathrm{mg} / \ell$ 


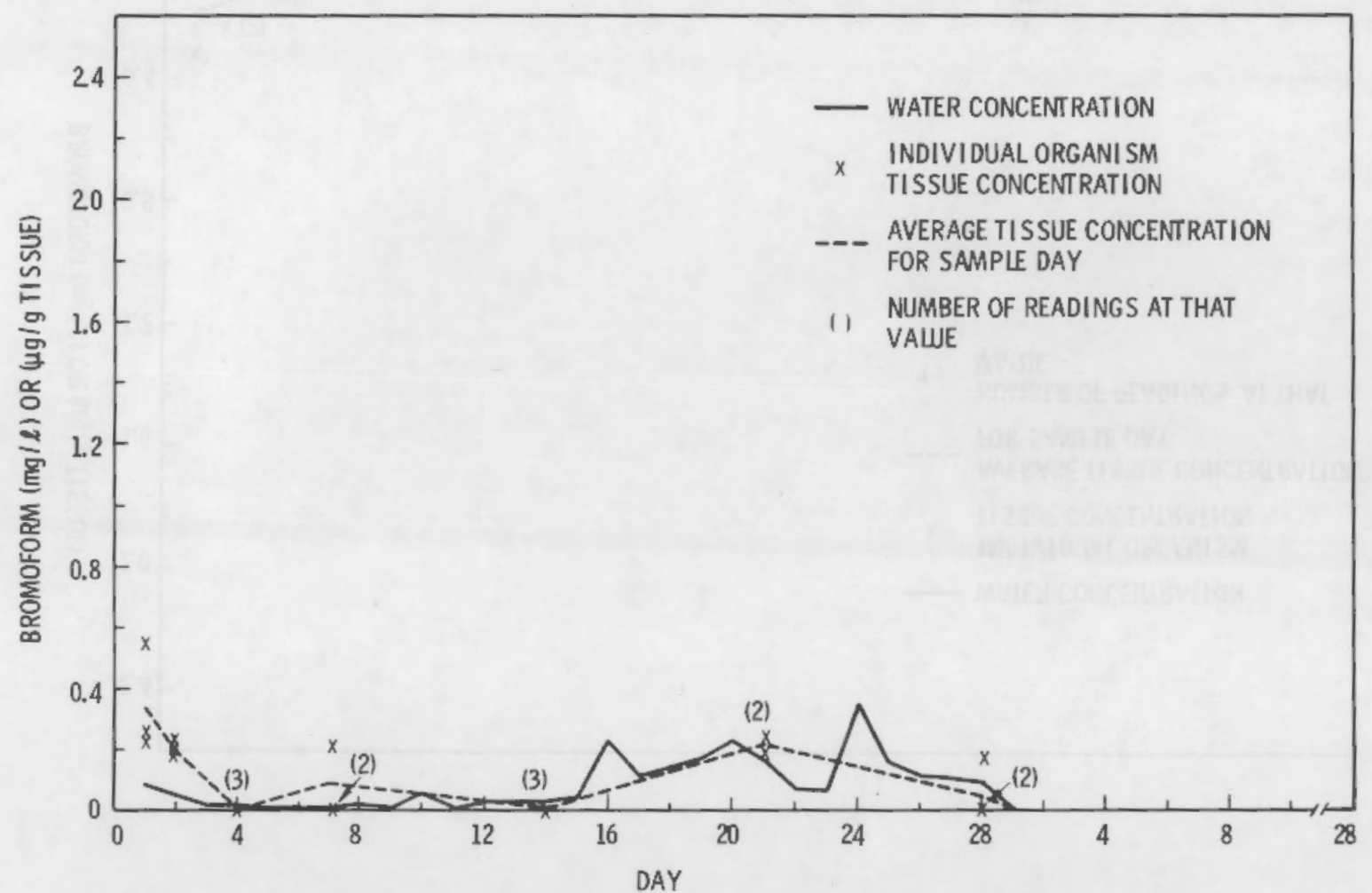

Figure 12. Water and tissue concentrations of bromoform (Eastern oyster, Crassostrea virginica) 28-day uptake/28-day depuration studies. 


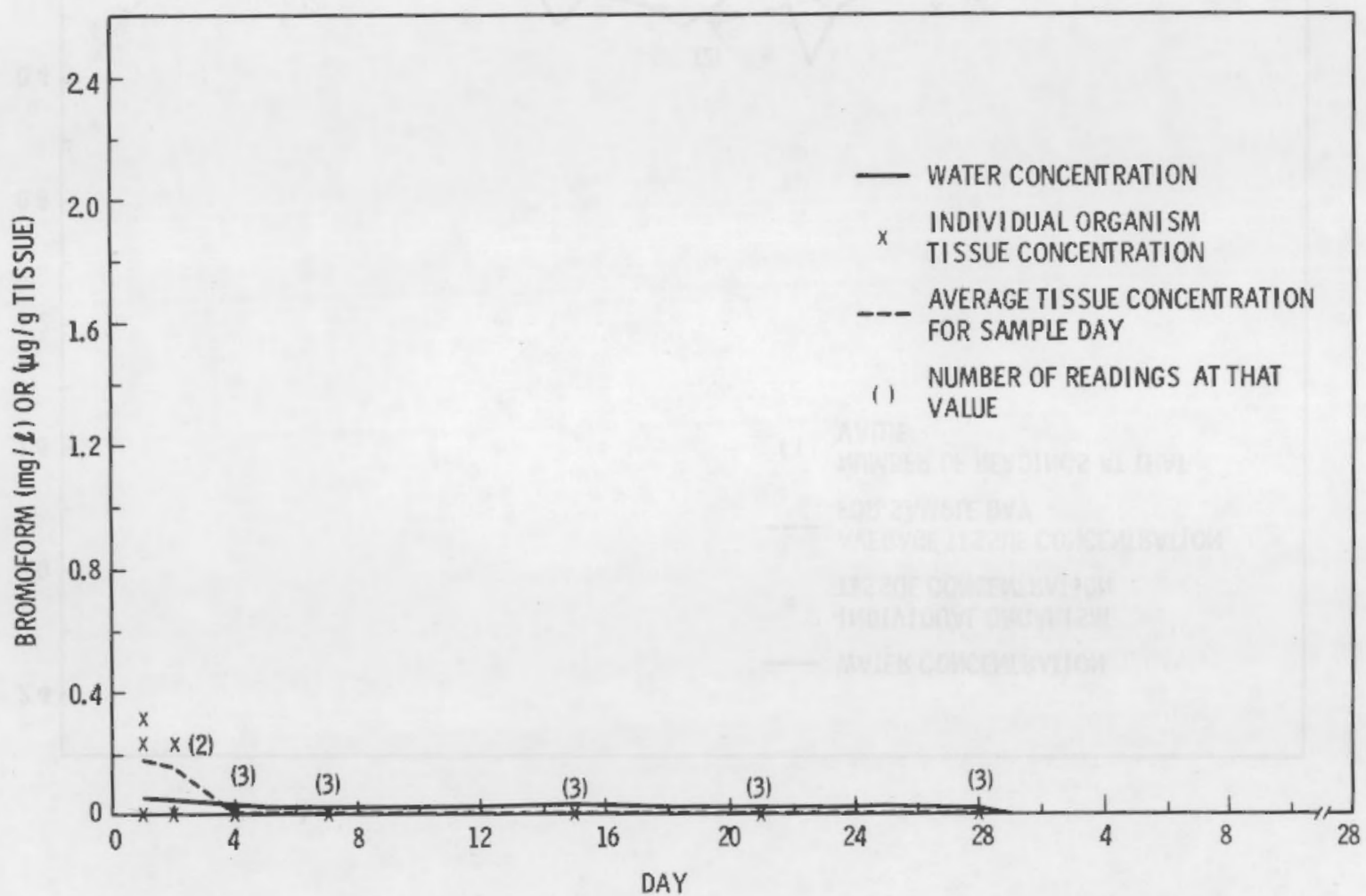

Figure 13. Water and tissue concentrations of bromoform (Eastern oyster, Crassostrea virginica) 28-day uptake/28-day depuration studies. Control 


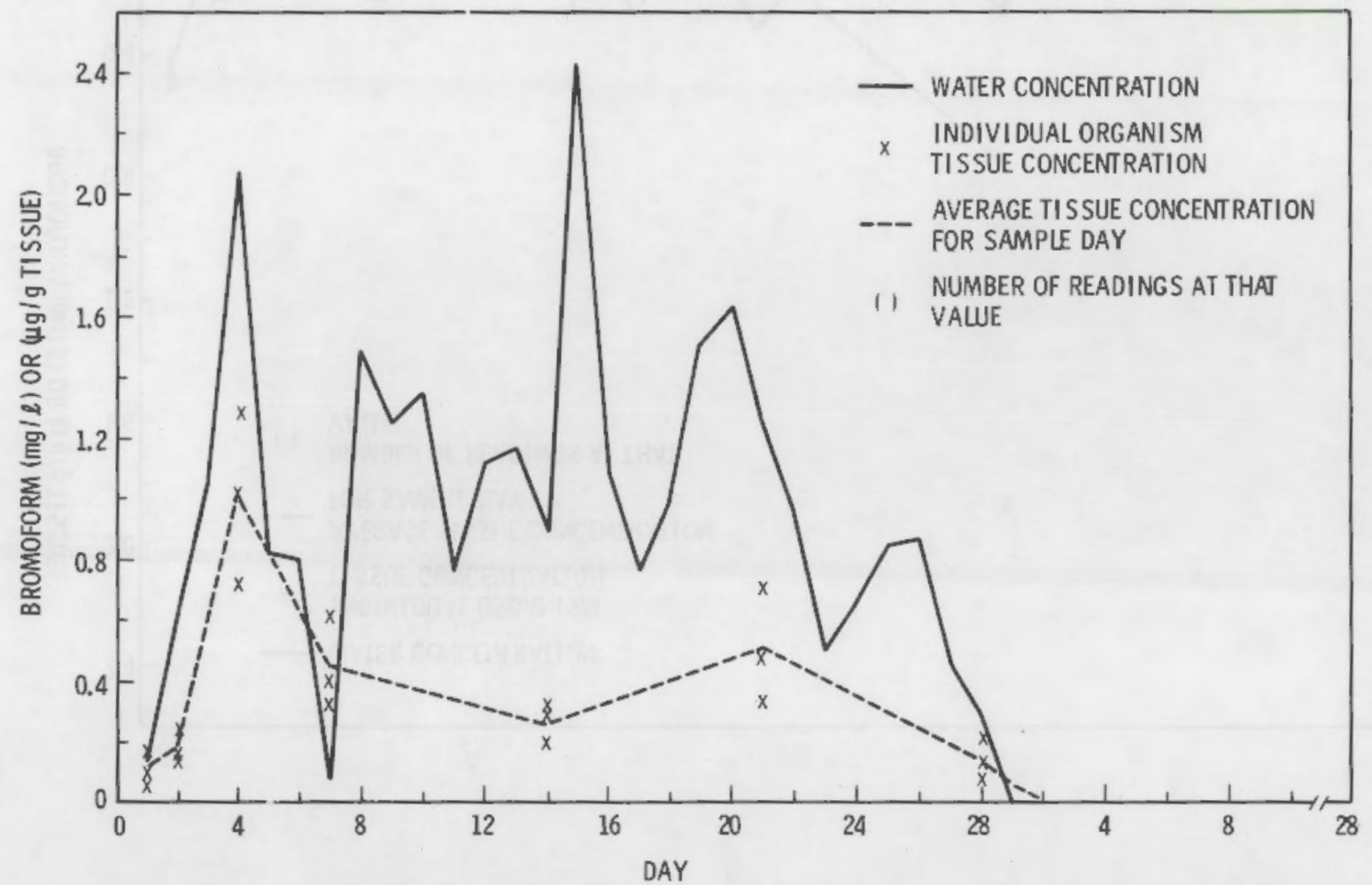

Figure 14. Water and tissue concentrations of bromoform (Quahaug, Mercenaria mercenaria) 28-day uptake/28-day depuration studies. Target water bromoform concentration was $1.0 \mathrm{mg} / \ell$ 


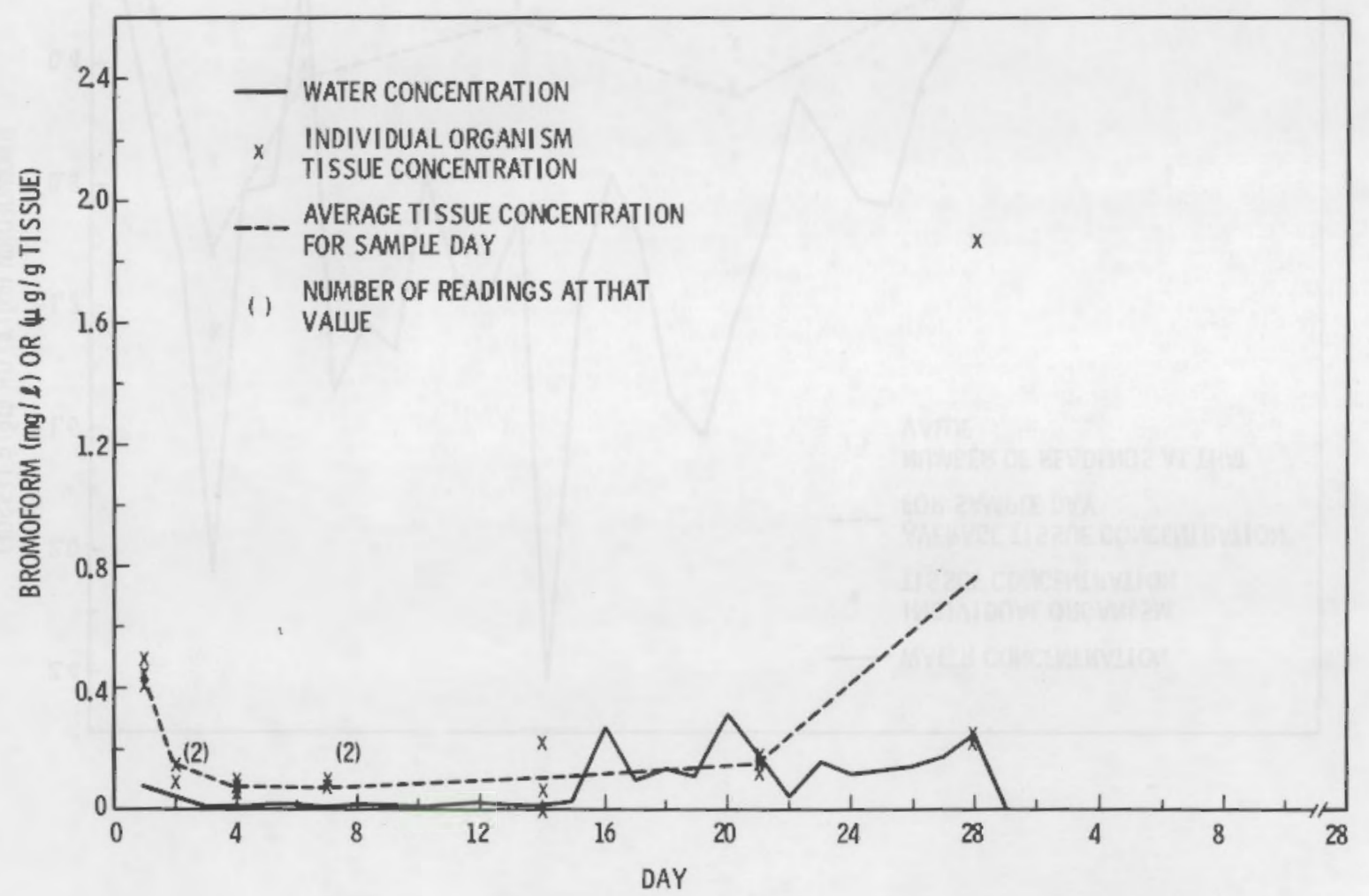

Figure 15. Water and tissue concentrations of bromoform (Quahaug, Mercenaria mercenaria) 28-day uptake/28-day depuration studies. Target water bromoform concentration was $0.1 \mathrm{mg} / \ell$ 


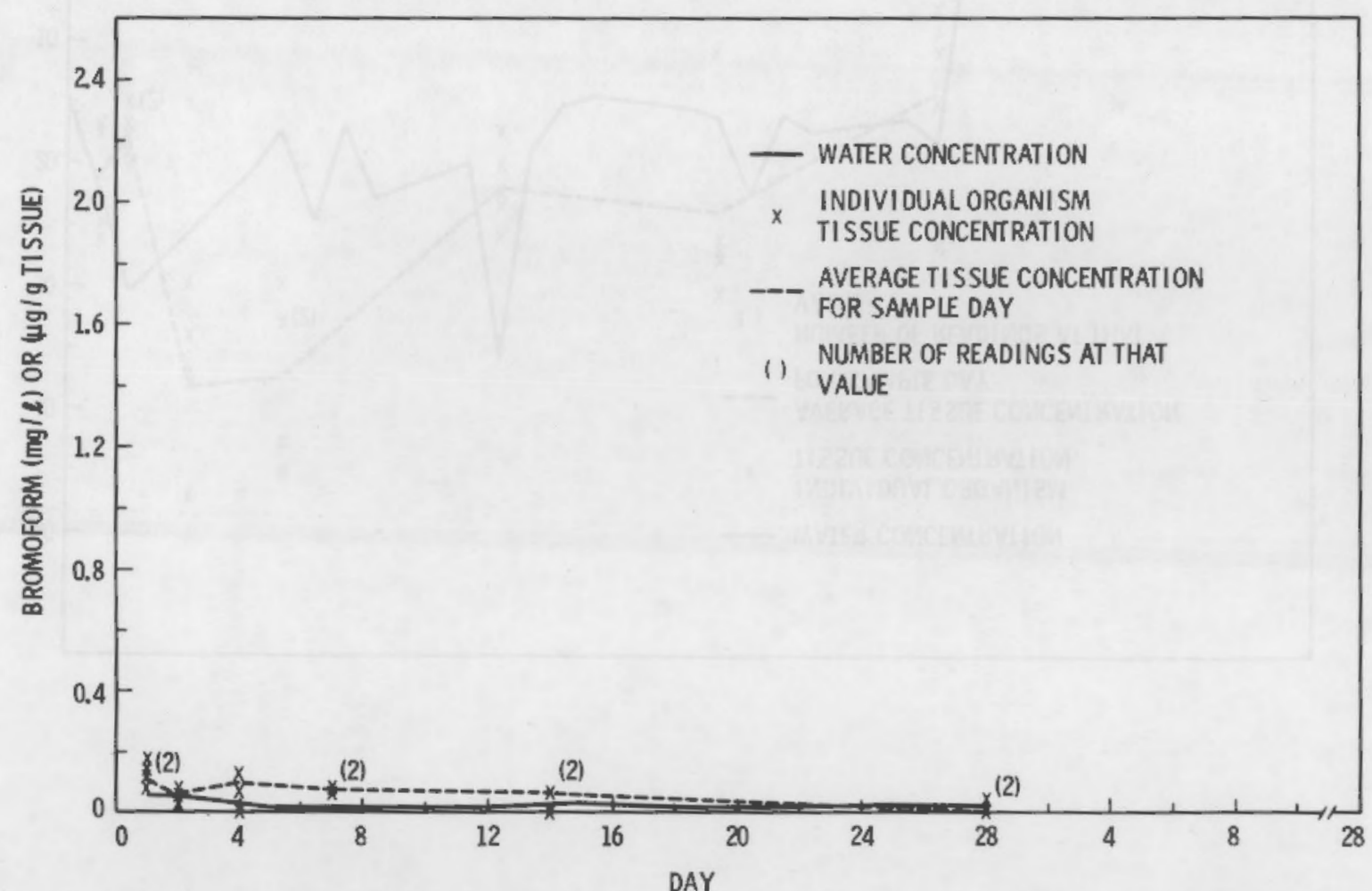

Figure 16. Water and tissue concentrations of bromoform (Quahaug, Mercenaria mercenaria) 28-day uptake/28-day depuration studies. Control 


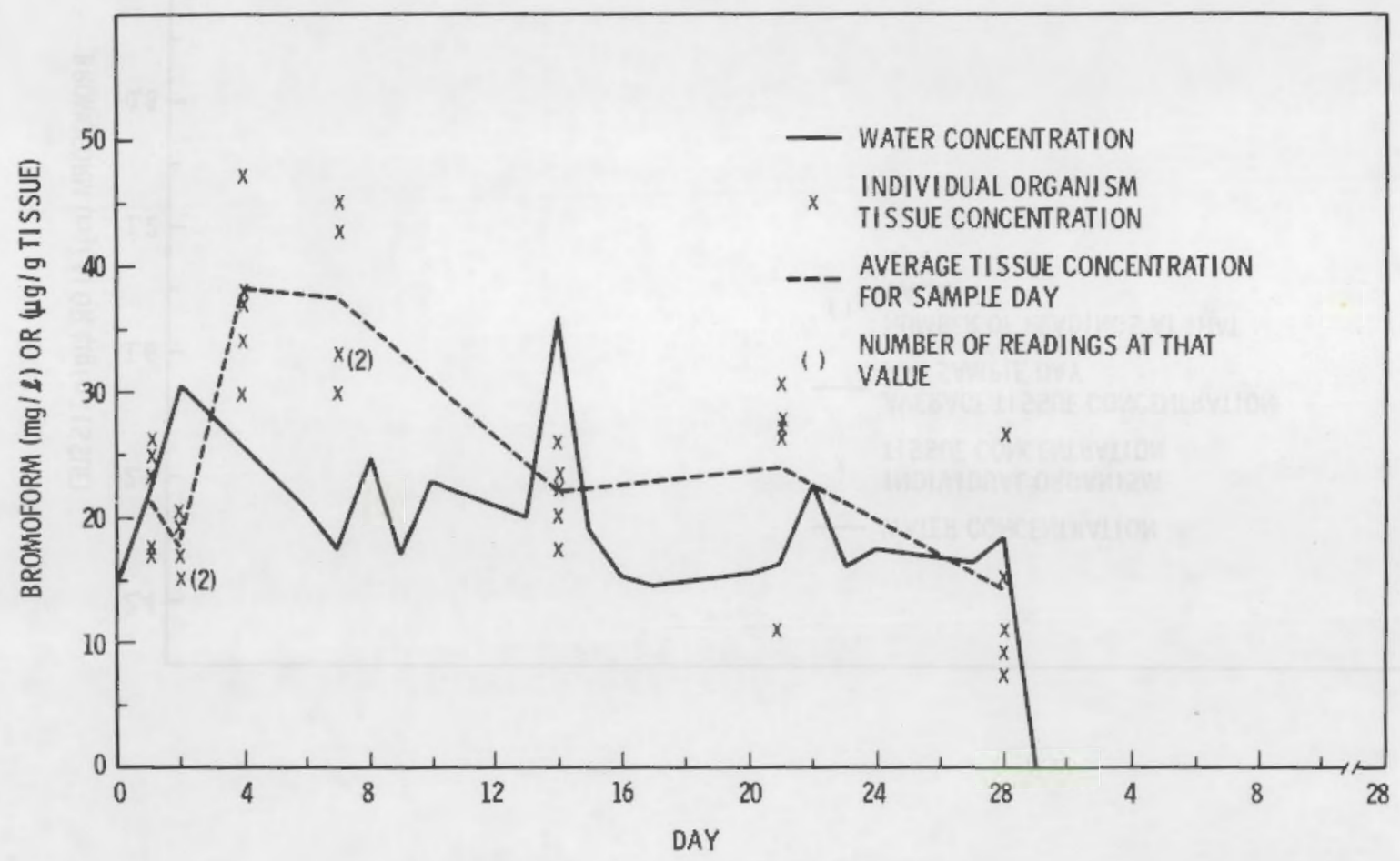

Figure 17. Water and tissue concentrations of bromoform (Littleneck clam, Protothaca staminea) 28-day uptake/28-day depuration studies. Target water bromoform concentration was $10 \mathrm{mg} / \mathrm{l}$ 


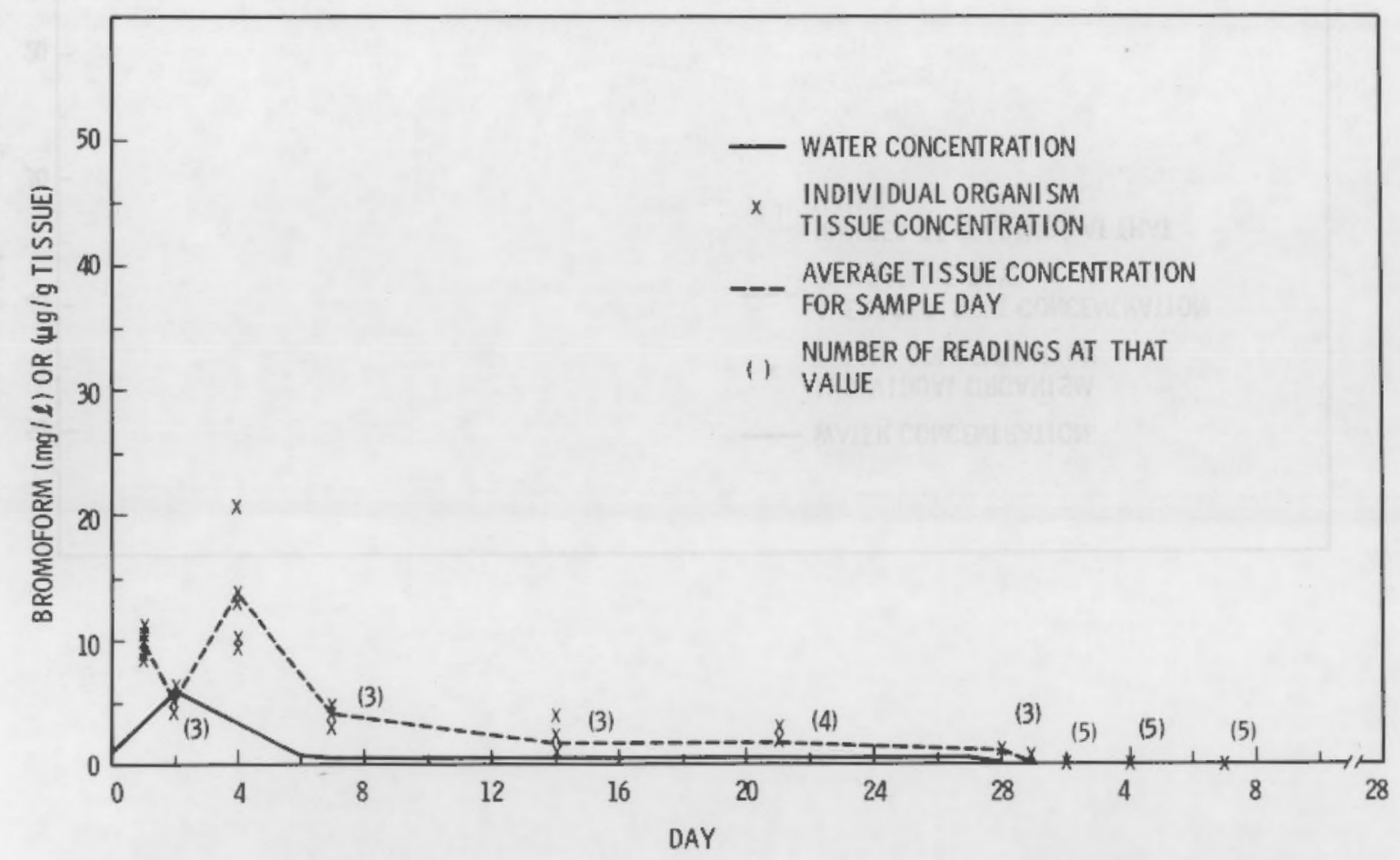

Figure 18. Water and tissue concentrations of bromoform (Littleneck clam, Protothaca staminea) 28-day uptake/28-day depuration studies. Target water bromoform concentartion was $1.0 \mathrm{mg} / \ell$ 


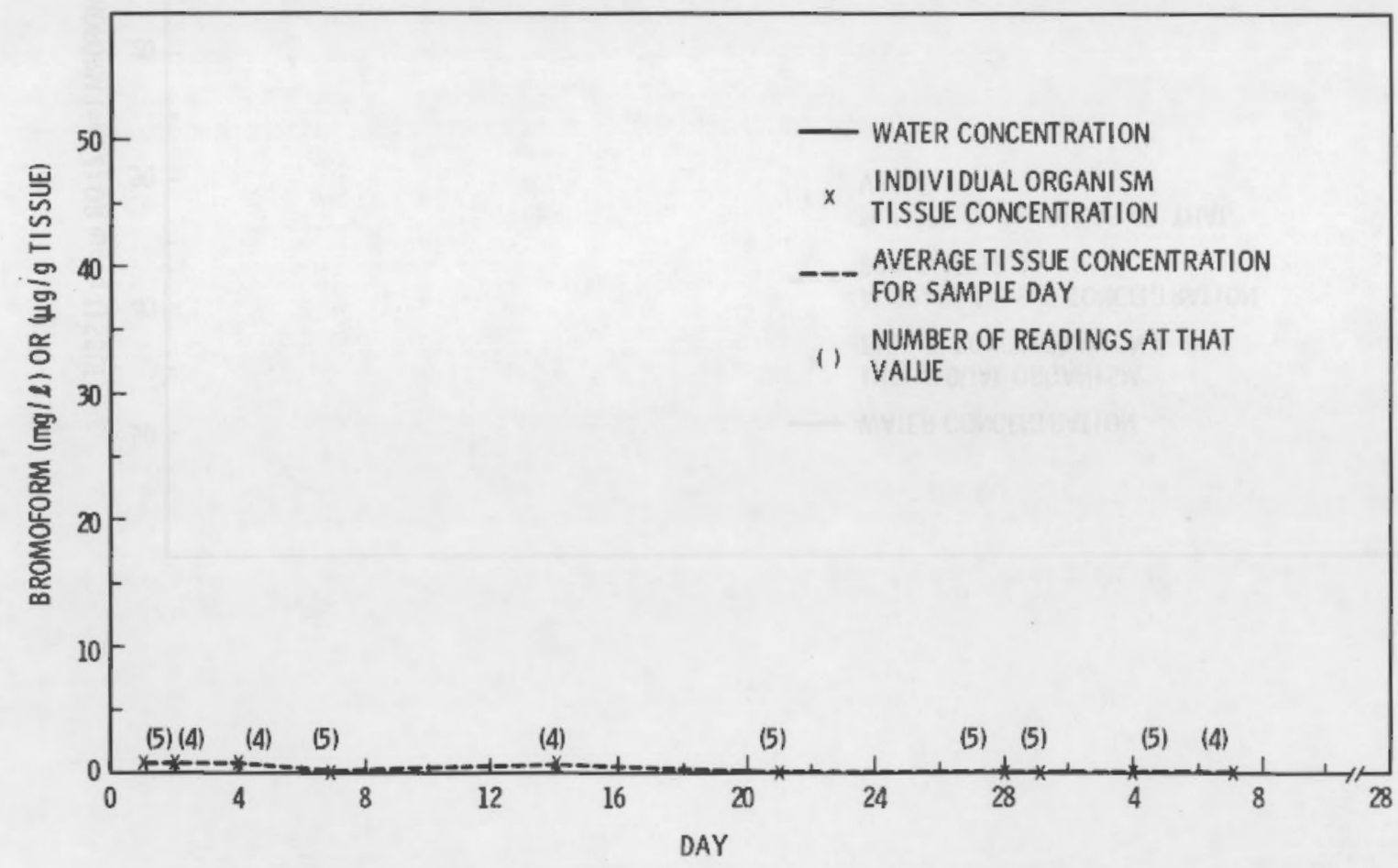

Figure 19. Water and tissue concentrations of bromoform (Littleneck clam, Protothaca staminea) 28-day uptake/28-day depuration studies. Control 


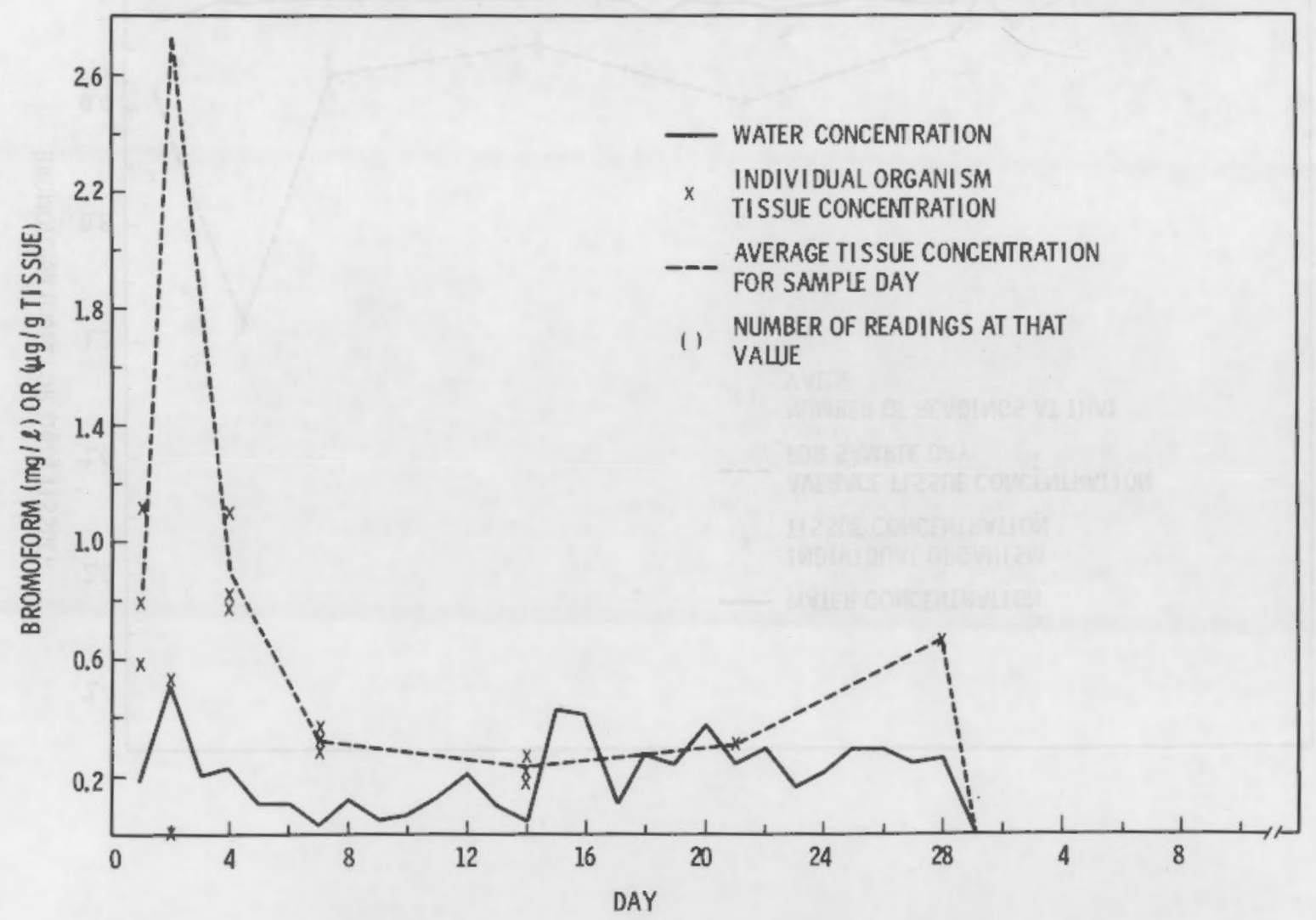

Figure 20. Water and tissue concentrations of bromoform (Menhaden, Brevoortia tyranus) 28-day uptake/28-day depuration studies. Target water bromoform concentrations was $1.0 \mathrm{mg} / \mathrm{\ell}$ 


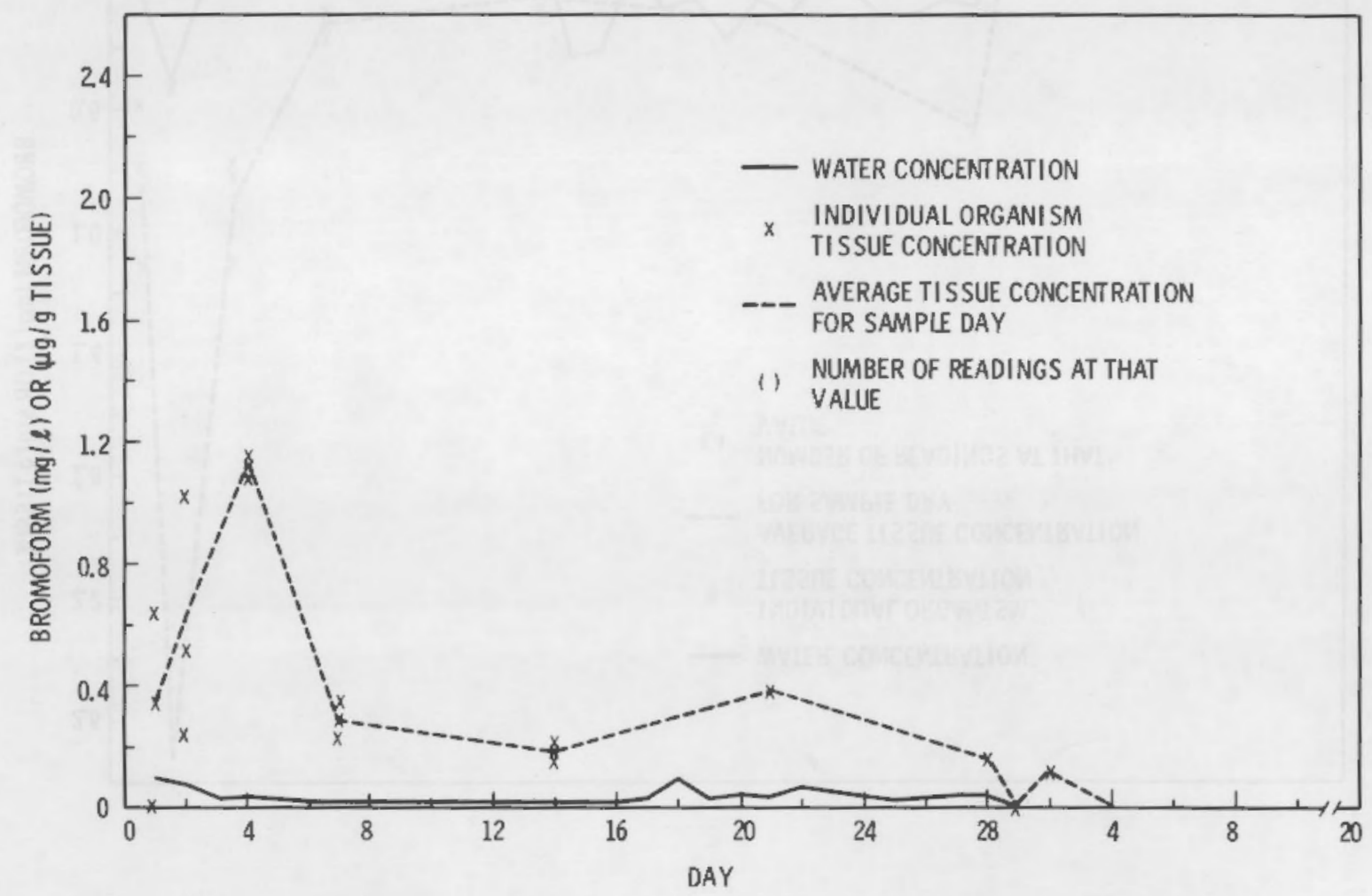

Figure 21. Water and tissue concentrations of bromoform (Menhaden, Brevoortia tyrannus) 28-day uptake/28-day depuration studies. Target water bromoform concentration was $0.1 \mathrm{mg} / \ell$ 


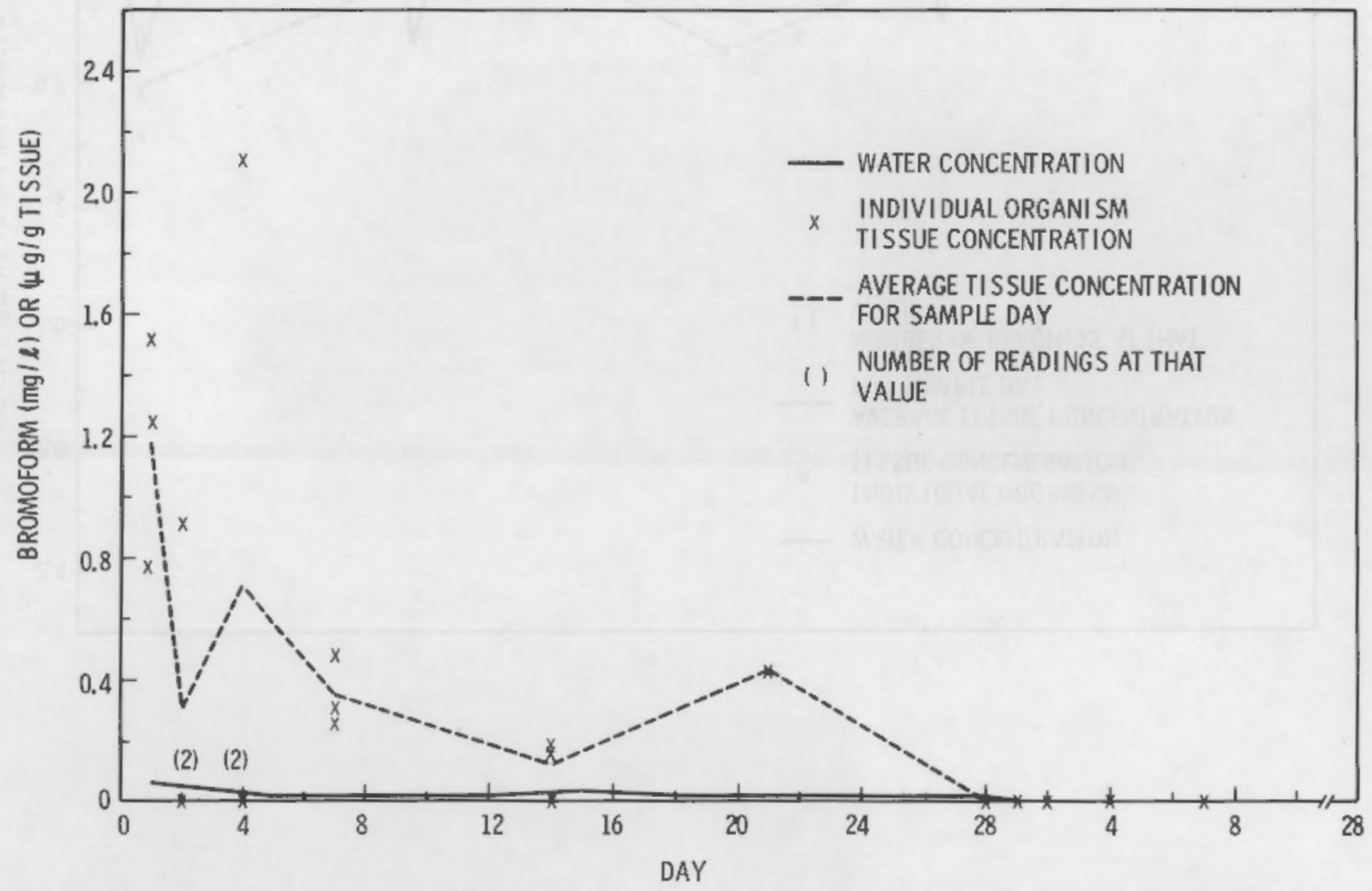

Figure 22. Water and tissue concentrations of bromoform (Menhaden, Brevoortia tyrannus) 28-day uptake/28-day depuration studies. Control 


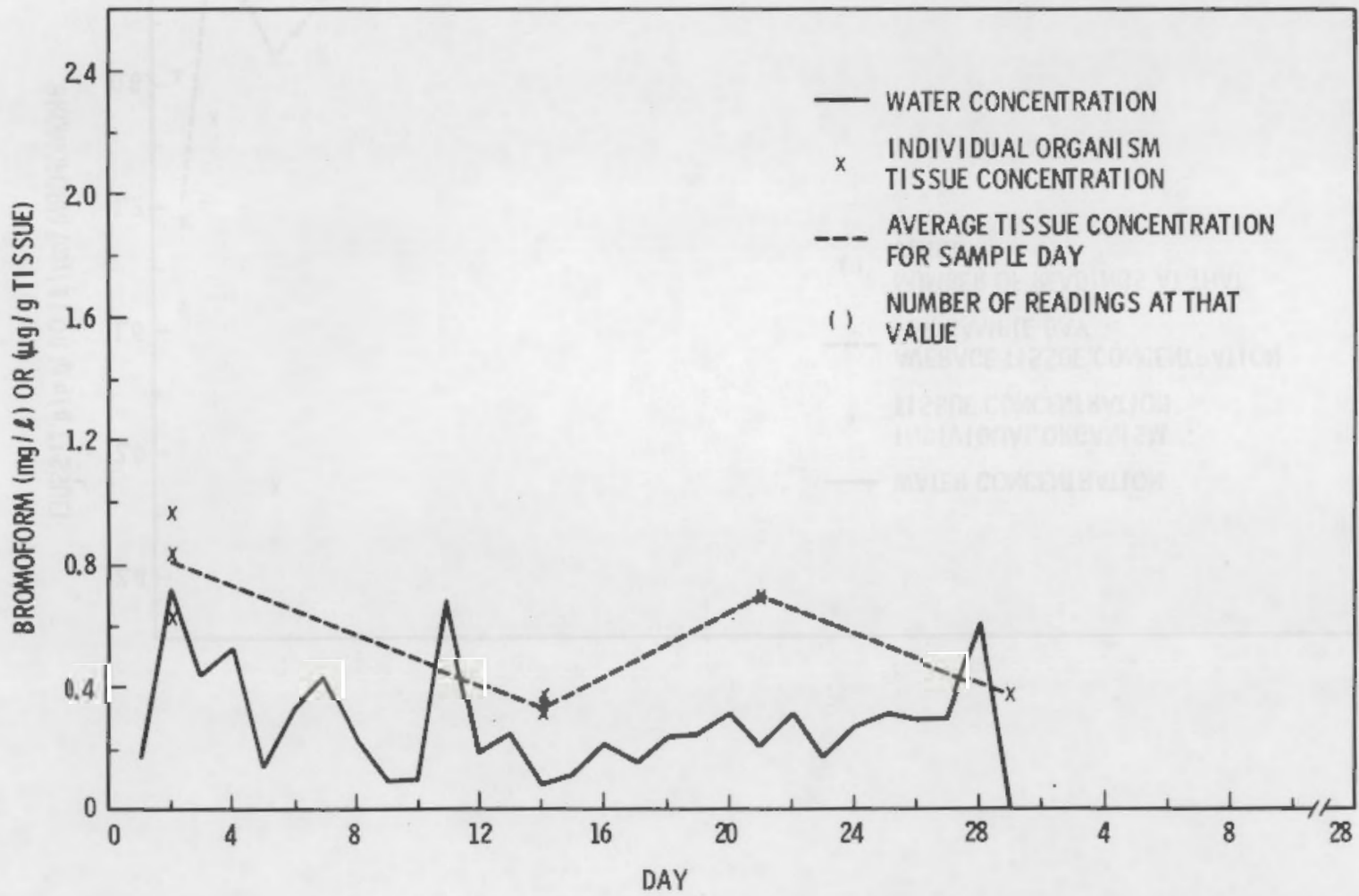

Figure 23. Water and tissue concentrations of bromoform (Shrimp, Penaeus azectus) 28-day uptake/28-day depuration studies. Target water bromoform concentration was $1.0 \mathrm{mg} / \mathrm{\ell}$ 


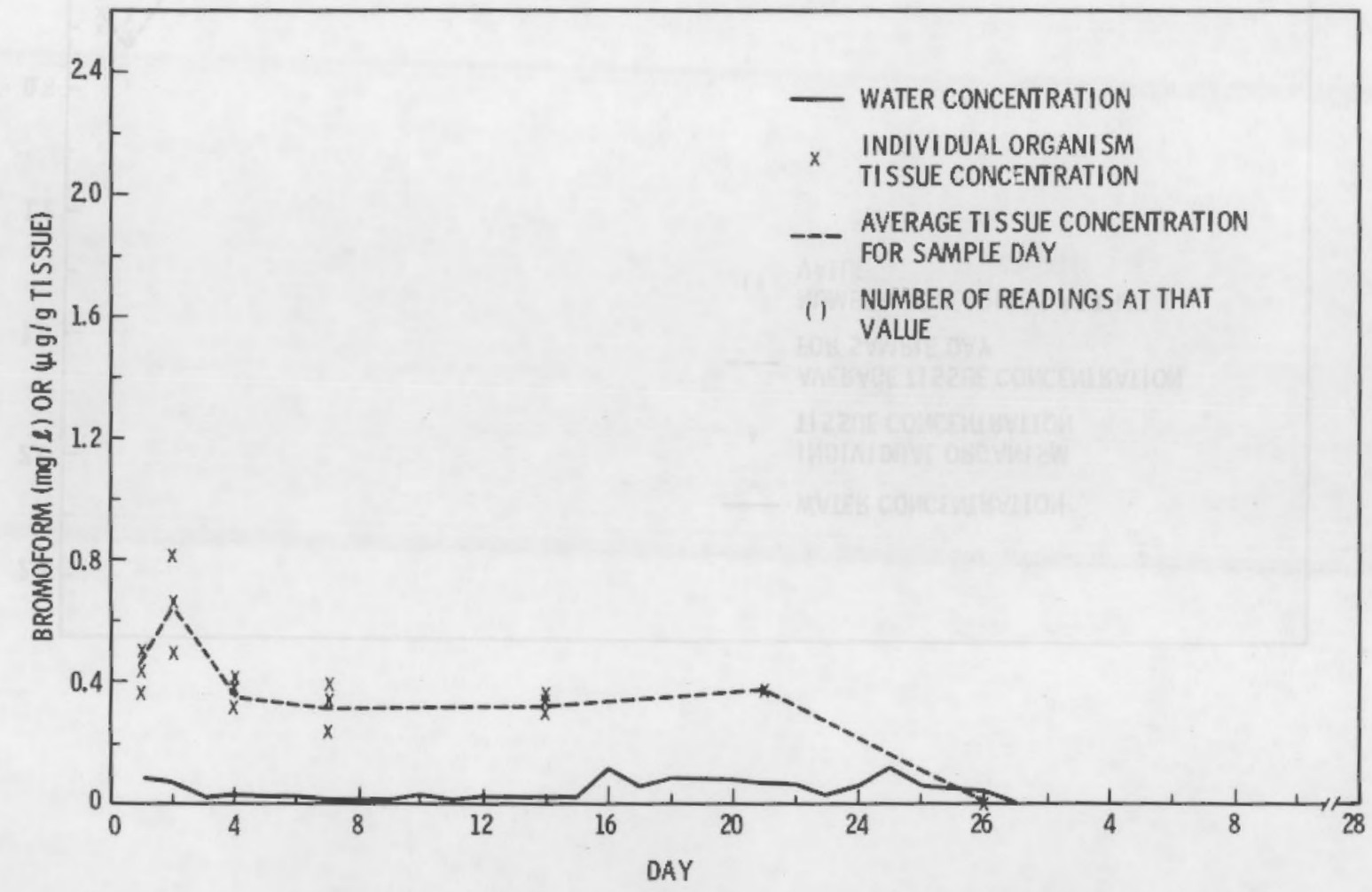

Figure 24. Water and tissue concentration of bromoform (Shrimp, Penaeus azectus) 28-day uptake/28-day depuration studies. Target water bromoform concentration was $0.1 \mathrm{mg} / \mathrm{\ell}$ 


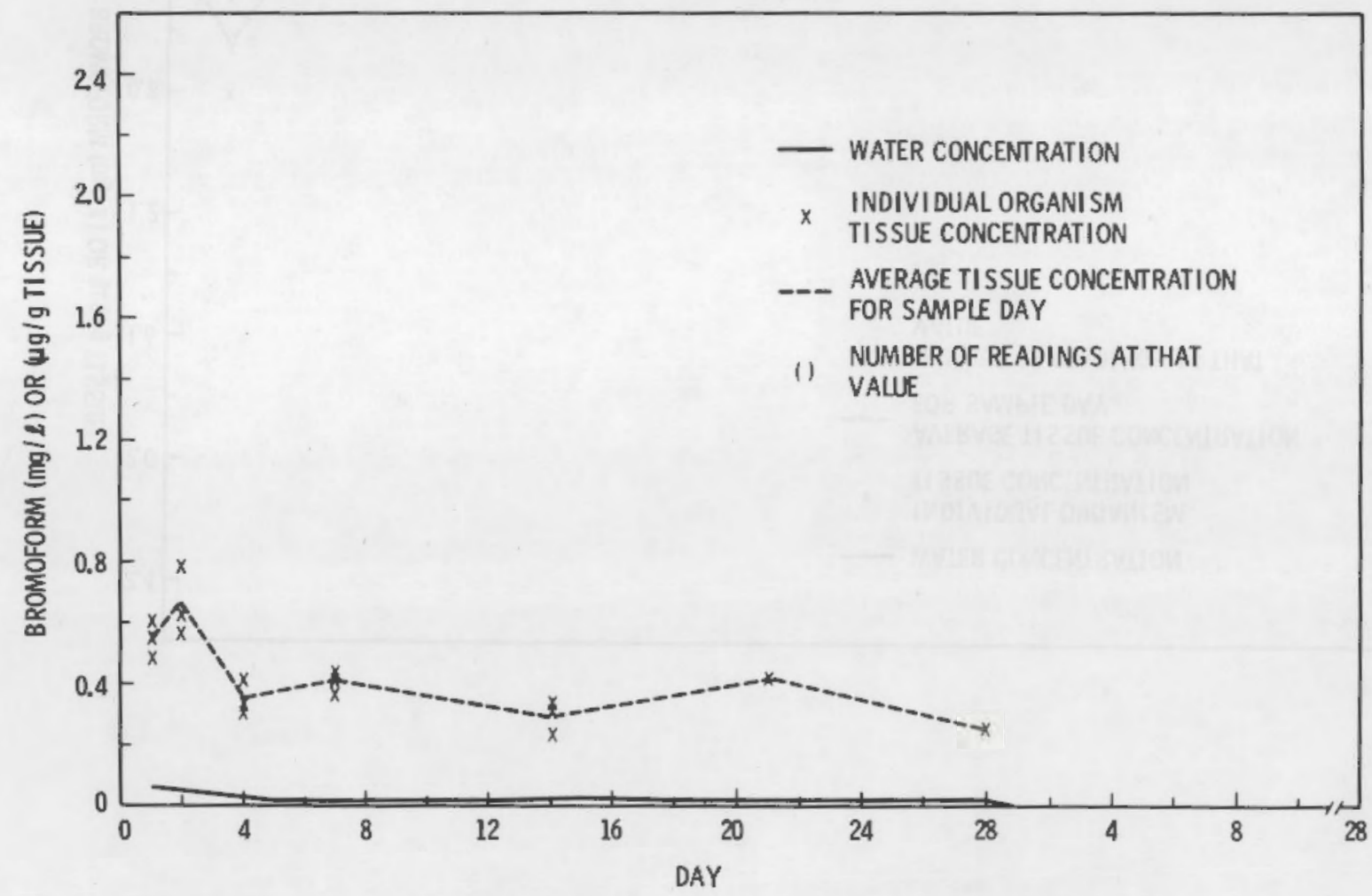

Figure 25. Water and tissue concentrations of bromoform (Shrimp, Penaeus aztecus) 28-day uptake/28-day depuration studies. Control 
No. of

Copies

\section{OFFSITE}

A. A. Churm

DOE Patent Division

$9800 \mathrm{~S}$. Cass Avenue

Argonne, IL 60439

Or. Phillip R. Reed

Bob Samworth

John C. Lehr

U.S. Nuclear Regulatory

Carmiss ion

7915 Eastern Avenue

Silver Springs, MD 20901

265 NRC Division of Technical

Information and Document Control

Washington, DC 20555

2 DOE Technical Information Center

D. R. Anderson

2521 N. 40th, No. 1

Seattle, WA 98103

Dr. Robert Broxton

Electric Power Research Institute

PO Box 10412

Palo Alto, CA 94303

Dr. Dennis T. Burton

Academy of Natural Sciences of Philadelphia

Benedict Estuarine Research Laboratory

Benedict, MD 20612
No. of

Copies

Dr. Will Davis

U.S.E.P.A.

Gulf Breeze Environmentul

Research Laboratory

Wadmalaw Is 1 and, SC 19487

Or. R. E. Hillman

W. F. Clapp Laboratories

Washington Street, P.0. Box AH

Duxbury, MA 02332

Or. Donald Johnson

Dept. Environmental Sciences and Engineering

School of Public Health

University of North Carolina

Chapel Hill, NC 27514

Dr. George R. Helz

Chemistry Dept.

University of Maryland

College Park, MD 20742

Dr. Milton H. Lietzke

PO Box $X$

Oak Ridge National Laboratory

Oak Ridge, TN 37830

Dr. J. S. Mattice

PO Box X

Oak Ridge National Laboratory

Oak Ridge, TN 37830

Or. John Lum

U.S.E.P.A.

401 M Street S.W.

WH552

Washington, DC 20460 
No. of

Copies

Dr. Roy Nakatani

Dr. Quentin J. Stober

FRI WH-10

University of Washington

Seattle, WA 98195

Dr. Thomas 0 . Thatcher

Rt 2 Box 113

Sequim, WA 98382

F. C. Tone

Florida Marine Research Facility Sailfish Drive

Ponce Inlet

Daytona Beach, FL 32019

Ronald L. Raschke

U.S. EPA

S.E. Water Laboratory

Bailey Road

Athens, GA 30601
No. of

Copies

ONSITE

50 Pacific Northwest Laboratory

RM Bean (32)

CI Gibson

KE Harding (4)

DC Mann

TL Page

RG Riley

RE Schirmer

NM Sherer

RE Wildung

Publishing Coordination (2)

Technical Information (5) 


\begin{tabular}{|c|c|}
\hline $\begin{array}{l}\text { U.8. MUCLEAR REOULATORY COMMISSION } \\
\text { BIBLIOGRAPHIC DATA SHEET }\end{array}$ & $\begin{array}{l}\text { 1. AEPOAT NUMEE R (Assigned by DOC) } \\
\text { NUREG/CR }-1297 \\
\text { PNL }-3157\end{array}$ \\
\hline \multirow{2}{*}{$\begin{array}{l}\text { 4. TITLE AND SUETITLE (Add Volume No. if epropriate) } \\
\text { Toxicity, Bioaccumulation and Depuration of Bromoform } \\
\text { in Five Marine Species }\end{array}$} & 2. (Leave biank) \\
\hline & 3. RECIPIENT'S ACCESSION NO. \\
\hline \multirow{2}{*}{$\begin{array}{l}\text { 7. AUTHOR(S) } \\
\text { C.I. Gibson, F.C. Tone, P. Wilkinson, J.W. Blaylock, } \\
\text { R.E. Schirmer }\end{array}$} & 5. DATE REPOAT COMPLETED \\
\hline & \begin{tabular}{|l|r|} 
MONTH & YEAR \\
August & 1980 \\
\end{tabular} \\
\hline \multirow{4}{*}{$\begin{array}{l}\text { 9. PERFORMING ORGANIZATION NAME AND MAILING ADDRESS Inciude Zio Code) } \\
\text { Pacific Northwest Laboratory } \\
\text { Richland, WA } 99352\end{array}$} & DATE REPORT ISSUED \\
\hline & \begin{tabular}{l|r|} 
MgNTH & Yafor \\
\end{tabular} \\
\hline & 6. (Leave bionk) \\
\hline & 8. (Leave blank) \\
\hline \multirow{2}{*}{$\begin{array}{l}\text { 12. SPONSORING ORGANIZATION NAME AND MAILING ADDRESS Hnclude } Z \text { ip Code) } \\
\text { U.S. Nuclear Regulatory Commission } \\
\text { Division of Safeguards, Fuel Cycle and } \\
\text { Environmental Research } \\
\text { Office of Nuclear Regulatory Research } \\
\text { Washington, DC } 20555\end{array}$} & 10. PROJECT/TASK/WORK UNIT NO. \\
\hline & $\begin{array}{l}\text { 11. CONTRACT NO. } \\
\text { FIN } 82098\end{array}$ \\
\hline 13. TYPE OF AEPORT & 0 (Inciusive dares) \\
\hline
\end{tabular}

15. SUPPLEMENTARY NOTES

14. (Leave biank)

16. ABSTRACT ROO words or less)

Bromoform has been identified as the single most abundant halogenated organic compound produced by the chlorination of marine waters. To determine the potential biological effects of its release into marine waters, short-term toxicity bioassays and 28 -day uptake/28-day depuration studies were conducted with five marine species: Protothaca staminea, Mercenaria mercenaria, Crassostrea virginica, Penaeus aztecus, and Brevoortia tyrannus. These species have commercial and economic importance and are of ten found in the vicinity of discharge streams from nuclear fueled steam electric stations.

\begin{tabular}{|c|c|}
\hline $\begin{array}{l}\text { 19. SECYAITY CLASS (This reoort) } \\
\text { nClass ified }\end{array}$ & 21. NO. OF PAGES \\
\hline 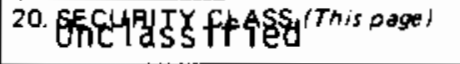 & $\begin{array}{l}\text { 22. PAICE } \\
\mathrm{S}\end{array}$ \\
\hline
\end{tabular}


